\title{
Sensitivity of Estuaries to Compound Flooding
}

\author{
Lisa M. Harrison ${ }^{1,2}\left(\mathbb{D} \cdot\right.$ Tom J. Coulthard ${ }^{2} \cdot$ Peter E. Robins $^{3} \cdot$ Matthew J. Lewis $^{3}$
}

Received: 3 March 2020 / Revised: 6 August 2021 / Accepted: 23 August 2021 / Published online: 13 October 2021

(c) The Author(s) 2021

\begin{abstract}
Fluvial and surge-tide extremes can occur synchronously resulting in compound flooding in estuaries, greatly intensifying the hazard. This flood risk has the potential to increase in the future as the frequency, phasing and/or intensity of these drivers change. Improved understanding of how extreme fluvial discharge and surge-tides interact will help inform future flood mitigation methodology. In this paper, therefore, we resolve for the first time intra-estuary sensitivities to fluvial and surgetide extremes, for two contrasting UK estuaries (Humber and Dyfi). Model simulations at hyper-spatial resolution $(<50 \mathrm{~m})$ using a 2D hydrodynamic model predicted compound flooding hazards based on: (1) present-day extreme events (worst on record); (2) present-day extreme events with shifted timings of the drivers to maximise flooding; and (3) modified drivers representing projected climate change. We found that in a small estuary with short-duration, high-intensity fluvial inputs (Dyfi), flood extent is sensitive to the relative timing of the fluvial and surge-tide drivers. In contrast, the relative timing of these drivers did not affect flooding in a larger estuary with a slower fluvial response to rainfall (Humber). In the Humber, extreme fluvial inputs during a compound hazard actually reduced maximum water depths in the outer estuary, compared with a surge-tide-only event. Projected future changes in these drivers by 2100 will increase compound flooding hazards: simulated sea-level rise scenarios predicted substantial and widespread flooding in both estuaries. However, projected increases in surge-tide behaved differently to sea-level rise of the same magnitude, resulting in a greater seawater influx and more flooding. Increased fluvial volumes were the weakest driver of estuarine flooding. In this paper we show how these interactions are complex and how the hydrodynamics vary considerably between different estuaries and sites within estuaries, making it difficult to generalise, use probabilistic or use 1D approaches for assessing compound flooding hazards. Hence, we contribute new knowledge and methods for catchment-to-coast impact modelling used for flood mitigation strategies.
\end{abstract}

Keywords Compound hazard $\cdot$ Storm surge $\cdot$ Flood $\cdot$ CAESAR-Lisflood $\cdot$ Estuaries

\section{Introduction}

Estuaries are at risk from compound flooding hazards caused by the interactions of high astronomical tide, storm surge, waves and high fluvial discharge (e.g. Lewis et al. 2019). With over 600 million people living in low-lying coastal

Communicated by Nathan Waltham

Tom J. Coulthard

T.Coulthard@hull.ac.uk

1 Energy and Environment Institute, University of Hull, Hull, UK

2 School of Environmental Sciences, University of Hull, Hull, UK

3 Centre for Applied Marine Sciences, School of Ocean Sciences, Bangor University, Anglesey, UK regions globally, flooding from compound hazards is an international issue (Muis et al. 2016), resulting in loss of life and damage to infrastructure, as well as environmental, health and societal impacts (Santos et al. 2017). Worse, compound flooding hazards have the potential to increase in the future due to sea-level rise and increased intensity/duration precipitation leading to increased fluvial discharge intensity (Bevacqua et al. 2019; Ehret et al. 2014; Milly et al. 2008; Wahl et al. 2015). Frequently, flood risk estimates consider only one driver or one hazard, or multiple hazards within a probabilistic approach.

Tides, surges and fluvial events can occur synchronously in estuaries and interact with one another, potentially altering the magnitude of the flood hazard both spatially and temporally, and the associated impacts and risks (Maskell et al. 2014; Klerk et al. 2015; Orton et al. 2018). For example, intense rainfall in catchments may coincide with high surge 
tide causing floodwaters to 'backup' behind the estuary with unexpected inundation significant distances upstream (Lewis et al. 2013; Zheng et al. 2013; Van Den Hurk et al. 2015; Wahl et al. 2015). The sensitivity of flooding to the timings of the drivers during extreme events makes resolving a compound hazard difficult; for example, a surge and high fluvial discharge arriving at low tide may pose no flood risk, with the converse true at high water (Zhong et al. 2013; Haigh et al. 2016). The difficulty in resolving flooding hazards further increases when accounting for variations in tidal regimes, surge and wave climates, catchment response types and estuarine morphology. However, the risk also changes spatially for each estuary depending on population demographics and land value at any given location (e.g. Monbaliu et al. 2014; Mansur et al. 2016).

Projected sea-level rise and changing weather patterns have been used to predict an increase in compound flooding in estuaries in the USA (Wahl et al. 2015), although relationships between climate change and compound hazards are complex and vary spatially (e.g. Orton et al. 2018). It has been shown for many estuaries around the world that there is a significant dependence between high fluvial discharge and skew surge (the difference between the local maximum observed water level and the maximum tidal level per tidal cycle) (Klerk et al. 2015; Ward et al. 2018); hence, estuarine systems are particularly vulnerable to increased compound flooding in the future (Zhong et al. 2013). Dependence between high river discharge and skew surge may not exist for all estuaries; however, climatic shifts in flood driver sources or pathways of flooding, may occur in the future (see Ward et al. 2018); for example, changes seasonality of river discharge, hydrograph shape (rainfall intensity or catchment process and land use), or estuary bathymetry will change the flood risk without changing individual flood driver extremes (i.e., return periods). Considering the evidence for cooccurrence between storm surges and fluvial extremes in some UK estuaries (e.g. Svensson and Jones 2002), and that both sea level and fluvial extremes are projected to change during this century (e.g. Woth et al. 2006; Robins et al. 2018; Lowe et al. 2019)—potentially resulting in increased flood risk (King 2004), there is a clear need to improve our understanding of the drivers of estuarine flooding. Indeed, the sensitivity to the resolution of flood-hazard drivers is poorly understood, e.g. sub-hourly fluvial forcing is required to resolve small or steep systems whereas daily-averaged forcing may be appropriate for larger systems (Wade et al. 2005; Lyddon et al. 2018; Robins et al. 2018).

Probabilistic methods to determine the joint probability and dependency of the drivers of estuary flooding are based on copulas, Bayesian networks, or bivariate extreme value models (Van Den Hurk et al. 2015; Petroliagkis et al. 2016; Zellou and Rahali 2019). These probabilistic methods, however, do not necessarily help us understand how these drivers can affect flood risk; for example, the effect of storm duration (Quinn et al. 2014), the synchronous effect of clusters of storms (Haigh et al. 2016), or the effect of different storm behaviours (Robins et al. 2018). Uncertainties in these probabilistic methods (see Winter et al. 2018), which are used to define the boundary conditions of estuary flood models, have been shown to cascade to larger uncertainty of flood risk (e.g. Lewis et al. 2011).

Deterministic flood models typically operate by solving the shallow water equations in two or three dimensions across a regular (gridded) or irregular framework (Bates et al. 2005). This generates spatially distributed outputs of flood depths, timings, velocities and extents. By mapping these flood characteristics to a range of socio-economic impacts, together with their likelihood of occurrence determined from probabilistic methods, the flood risk can be estimated and used to identify social and infrastructure sensitivities (Bates et al. 2005; Neal et al. 2011; Vousdoukas et al. 2016; Yin et al. 2016). Deterministic flood models require large amounts of environmental data for boundary conditions (e.g. bathymetry, sea level, wind and fluvial discharge data). Errors within data or coarse resolution of these data can propagate through space and time leading to estimates of flooding that contain a high degree of uncertainty (Teng et al. 2017). Two- and three-dimensional models may also be computationally expensive, which can restrict their use for estuary flood modelling that requires high spatio-temporal resolution (Bates et al. 2005). Hence, quantifying flood risk uncertainty can become a difficult task computationally within a deterministic framework, which restricts model applicability for large or complex domains with multiple drivers and uncertainties (e.g. estuaries). Hence, we shall apply a reduced complexity model (LISFLOOD-FP, see Bates et al. 2010) that, using the inertia-wave, is computationally inexpensive and accurate at simulating flooding in estuaries (e.g. Maskell et al. 2014; Ramirez et al. 2016; Skinner et al. 2015; Yin et al. 2016) and at European scale (Vousdoukas et al. 2016).

In this paper, we aim to improve current understanding of estuary compound flooding hazards. We will employ a deterministic modelling approach using the CAESAR-Lisflood (CL) model (Coulthard et al. 2013). The simplified inertial wave approximation solver, often used for simulation flooding, allows flood modelling using fine-resolution DEMs $(<90 \mathrm{~m})$ over large regional areas (Lewis et al. 2013; Ramirez et al. 2016), and can directly simulate the effect of surge, fluvial discharge and tide acting together on the volume of water within the estuary. This allows the simulation of the important nuances of flooding, as well as nonlinear interactions such as volume and momentum effects, backing up of flow, water storage when overbank and return flows, to generate detailed spatial and temporal forecasts of flooding. Models will capture event dynamics at scales not 
previously carried out and provide detailed spatial information on flood areas and flood durations. Hence, $\mathrm{CL}$ is a novel tool for application to compound flooding hazards in estuaries. By contrasting two estuary typologies and simulating compound flooding hazards within a sensitivity framework, we will address the following questions:

1. How sensitive are estuarine maximum water depths to the timing of surge-fluvial phasing?

2. Which drivers (fluvial/sea level rise/surge height) are the most significant source of increased maximum water depths for two estuary types?
3. How do potential future changes in the drivers influence max estuary depths?

\section{Methods}

\section{Study Areas}

Two contrasting UK catchments and estuaries were studied: the Humber estuary and the Dyfi estuary, shown in Fig. 1 and detailed in Table 1. The Humber is the second largest estuary in the UK and its catchment drains one of
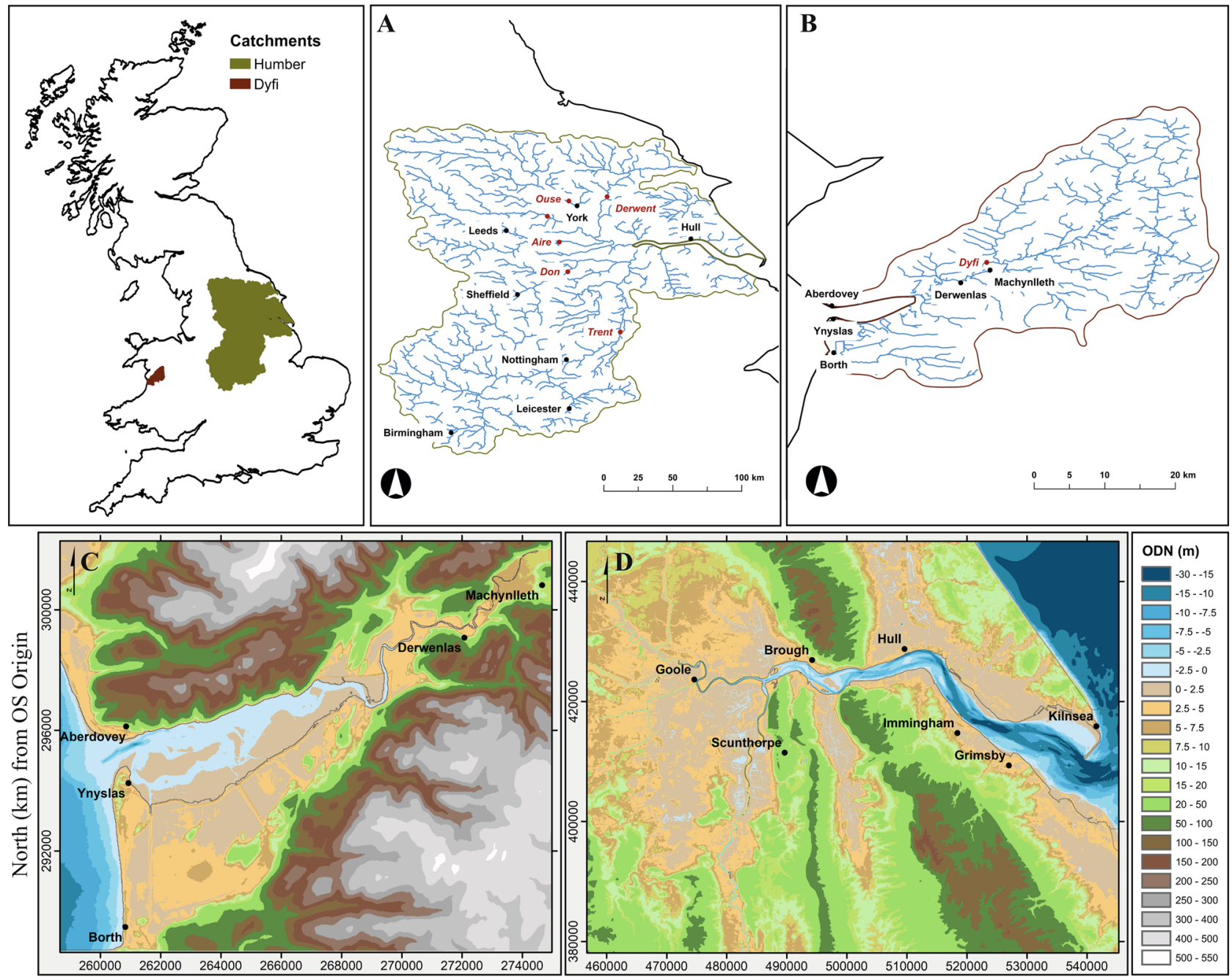

East $(\mathrm{km})$ from OS Origin

Fig. 1 Map of Britain showing the location of the (A) Humber and (B) Dyfi estuaries and their drainage basin extents. Prominent locations are labelled in black. Fluvial gauge stations from which data was acquired are labelled in red, which also marks the upstream model domain extent 
Table 1 Humber and Dyfi Estuary information

\begin{tabular}{|c|c|c|}
\hline & Humber estuary & Dyfi estuary \\
\hline Location & East England & West Wales \\
\hline Area & $24,240 \mathrm{~km}^{2}$ & $470 \mathrm{~km}^{2}$ \\
\hline Geology & $\begin{array}{l}\text { Permeable carboniferous millstone grits and lime- } \\
\text { stone's in the headwaters, reworked glacial sands } \\
\text { and gravels downstream (Law et al. 1997) }\end{array}$ & $\begin{array}{l}\text { Impermeable Silurian formations, minor Boulder Clay } \\
\text { and alluvium deposits }\end{array}$ \\
\hline Annual rainfall & $\begin{array}{l}1600 \mathrm{~mm} \text { p.a. in the headwaters to down to } 600 \mathrm{~mm} \\
\text { p.a. at Trent Falls (Law et al. 1997) }\end{array}$ & $\begin{array}{l}>2000 \mathrm{~mm} \text { p.a. in the headwaters, decreasing to } \mathrm{c} . \\
1000 \mathrm{~mm} \text { p.a. at the coast }\end{array}$ \\
\hline Length & $62 \mathrm{~km}$ & $9 \mathrm{~km}$ \\
\hline Tidal limit & 147 km (River Trent) & $\sim 13 \mathrm{~km}$ (around Derwenlas) \\
\hline Estuary mouth & $\begin{array}{l}\text { Partially blocked by Spurn Point, effective } \\
\text { width } \sim 6 \mathrm{~km}\end{array}$ & $\begin{array}{l}\text { Bar-enclosed, effective width } \sim 0.8 \mathrm{~km} \text { (Robins and } \\
\text { Davies 2010) }\end{array}$ \\
\hline Spring tidal range & $5.8 \mathrm{~m}$ & 4.9 m (Shi 1993) \\
\hline Estuary type & $\begin{array}{l}\text { Macrotidal, tidally dominant and well mixed } \\
\text { (Townend and Whitehead 2003) }\end{array}$ & Macrotidal and well mixed (Robins and Davies 2010) \\
\hline Tidal gauge station & Immingham (1953-present) & Barmouth (1991-present) \\
\hline Response type & $\begin{array}{l}\text { Shallow fluvial gradients, slow response estuary } \\
\text { (Robins et al. 2018) }\end{array}$ & Steep fluvial gradients, rapid response catchment \\
\hline Largest fluvial inputs & $\begin{array}{l}\text { River Trent (mean daily flow } 89 \mathrm{~m}^{3} \mathrm{~s}^{-1} \text { ) River Ouse } \\
\text { (mean daily flow } 51 \mathrm{~m}^{3} \mathrm{~s}^{-1} \text { ) River Aire (mean daily } \\
\text { flow } 36 \mathrm{~m}^{3} \mathrm{~s}^{-1} \text { ) }\end{array}$ & Afon Dyfi (mean daily flow $23.5 \mathrm{~m}^{3} \mathrm{~s}^{-1}$ ) \\
\hline Combined fluvial input & $250 \mathrm{~m}^{3} \mathrm{~s}^{-1}\left(\right.$ high flow $\left.=1600 \mathrm{~m}^{3} \mathrm{~s}^{-1}\right)$ & - \\
\hline 95th percentile flow & $58 \mathrm{~m}^{3} \mathrm{~s}^{-1}(1980-2015)$ & $2.35 \mathrm{~m}^{3} \mathrm{~s}^{-1}$ (between 1962 and 2014) \\
\hline 10th percentile flow & $610 \mathrm{~m}^{3} \mathrm{~s}^{-1}(1980-2015)$ & $54.76 \mathrm{~m}^{3} \mathrm{~s}^{-1}$ (between 1962 and 2014) \\
\hline Largest floods on record & $>1400 \mathrm{~m}^{3} \mathrm{~s}^{-1}, 04 / 11 / 2000$ & $>400 \mathrm{~m}^{3} \mathrm{~s}^{-1}, 05 / 12 / 1979$ \\
\hline Largest storm surge on record & $+1.9 \mathrm{~m}, 05 / 12 / 2013$ & $+1.476 \mathrm{~m}, 24 / 12 / 1997$ \\
\hline
\end{tabular}

the largest fluvial systems (Robins et al. 2018). The estuary is located on the east coast of Britain and is defined as coastal-plain, being shallow, funnel-shaped and partially blocked at the mouth by a spit (Spurn Point). In contrast, the Dyfi is a considerably smaller, bar-built, estuary situated on the west coast of Britain. They experience different tidal regimes (although both macro-tidal) and because they are located on opposite coastlines, they experience different atmospheric conditions. The Dyfi catchment receives, on average, higher rainfall (Table 1), and wind speeds than the Humber, (Met Office 2019) and due to the prevailing south westerlies, surges and precipitation hit simultaneously (Svensson and Jones 2004). In the Humber, storms bringing high skew surges track north of Scotland, whereas those bringing higher precipitation events tract across the central UK in a west-east direction (Hendry et al. 2019). As well as contrasting in location, size and type, these catchments have different land uses and geology (Law et al. 1997; Pye and Blott 2014). Therefore, they represent two systems of different character upon which to evaluate compound flooding hazards.

\section{Model Setup}

CAESAR-Lisflood (CL) is a morphodynamic model developed primarily for simulating drainage basin response to environmental changes (climate and land use). It incorporates the $2 \mathrm{D}$ inertial wave approximation, to solve hydrodynamic flow (see Bates et al. 2010), with an integrated hydrological model based on Topmodel (Beven and Kirkby 1979). The hydrodynamic component has been successfully applied in estuary and coastal environments (Ramirez et al. 2016), including validation against compound tidal and surge events in the Humber Estuary (Skinner et al. 2015). Here, it is utilized solely as a hydrodynamic model. A full description of the model, its driving equations and validation can be found in Coulthard et al. (2013). Furthermore, the code is open source and details of where it can be downloaded are provided in the acknowledgements.

High temporal resolution fluvial data from river gauges (15-min flux time-series in $\mathrm{m}^{3} / \mathrm{s}$ ) upstream of the Humber and Dyfi estuaries (see Robins et al. 2018) were used as fluvial boundary conditions for the modelling. Sea level data 
at 15-min resolution was used to drive the coastal model boundaries: derived from the Barmouth tide gauge for the Dyfi (www.ntslf.org), and from the Spurn Point tide gauge for the Humber (Associated British Ports, ABP). Digital elevation models (DEMs) were created by combining multiple data sources, with spatial resolution of the DEMs chosen to maximise accuracy but with efficient model run times (i.e. $<1$ day per event simulation). DEM resolution was $50 \mathrm{~m}$ for the Humber, which explicitly resolves the 2021 flood defence heights/positions (data provided by the Environment Agency; C. Skinner, personal communication) and elevations along Spurn Point including the breached section which occurred during the 2013 surge (manually checked using $20171 \mathrm{~m} \mathrm{LiDAR}$ data). Due to there being insufficient bathymetry data for the river beds in the upper Humber region beyond Goole, a constant river bed elevation of $-3 \mathrm{~m}$ ODN was burnt into the DEM (C. Skinner, personal communication). The upper extent of the fluvial region of the Humber DEM was trimmed according to the river gauge stations listed in Table 2 and marked in red on Fig. 1. 'Glass walls' were built along the banks of the rivers where the bathymetry was unknown thus channelling fluvial discharges directly to the estuary.

The Dyfi estuary DEM was created using $5 \mathrm{~m}$ OS digital terrain model (DTM) and digital surface model (DSM) data merged with bathymetry data of the estuary and river bed obtained from Admiralty data combined with boat surveys (see Robins et al. 2011 and Dausse et al. 2012). The datasets were rasterised to a new DEM with a 20 -m cell size, including present-day flood defence data obtained from Natural Resources Wales. The upper extent of the fluvial region of the DEM was trimmed to the Machynlleth Bridge gauge station on the River Dyfi. Because this gauge station was close to the tidal limit, 'glass walls' along the river banks were not built into the Dyfi DEM.

A series of simulations were carried out for both estuaries including a baseline model per estuary with no flood events, worst-case scenarios with compound flooding of the largest present-day events on record and a series of climate change scenarios listed in Table 3 . The worst-case and climate change model runs are further explained in the sections 'Sensitivity Analysis: Fluvial-Surge Phasing' and 'Climate Change Sensitivity Analysis', respectively. Model outputs were maps of maximum water elevation (i.e. the maximum flood depth plus cell elevation per raster cell over the whole model run, rather than the maximum flood depth at any one time period/model iteration) and these were subtracted from the baseline model output maximum water elevations to create water elevation difference maps, subsequently used to investigate compound flooding and its sensitivity to the drivers.

\section{Sensitivity Analysis: Fluvial-Surge Phasing}

A sensitivity analysis was undertaken whereby the timing of the highest recorded fluvial discharge was shifted relative to the timing of the highest recorded storm surge, to understand the effect of the relative phasing of these drivers on estuary flooding. For the Humber, the $+1.9 \mathrm{~m}$ storm surge event which occurred on $05 / 12 / 2013$ on a spring tide was used. Peak fluvial discharge $\left(>1400 \mathrm{~m}^{3} \mathrm{~s}^{-1}\right)$ from the $04 / 11 / 2000$ event was phased in hourly intervals within $\mathrm{a} \pm 12 \mathrm{~h}$ window before and after the occurrence of the surge event (run $\mathrm{H} 4$ in Table 3). A second sensitivity analysis, for the Humber only, was undertaken with the two largest rivers of the Humber (Ouse and Trent) to characterise the discrete impact of each river on flood behaviour in compound with the 05/12/2013 surge. These scenarios (runs H5-H7 in Table 3) simulated a surge in compound with floods in either the Ouse or the Trent or both, while the other rivers were run with the mean daily fluvial discharge. The timings of the fluvial events were based upon the worst-case flooding simulated by the previous fluvial-surge phasing sensitivity analysis.

For the Dyfi, the $+1.16 \mathrm{~m}$ storm surge event which occurred on 25/11/2000 was chosen (see below). Peak fluvial discharge $\left(>400 \mathrm{~m}^{3} \mathrm{~s}^{-1}\right)$ from the $05 / 12 / 1979$ event was phased in 15 -min intervals within a \pm 2 -h window before and

Table 2 Gauge stations used for the extended Humber estuary and Dyfi estuary fluvial regions

\begin{tabular}{llllll}
\hline River & Location & Gauge number & Grid ref & Operating since & Gauge type \\
\hline Don & Doncaster & 27,021 & SE5697703973 & $01 / 1959$ & Ultrasonic gauge \\
Went & Walden Stubbs & 27,064 & SE5506416309 & $01 / 1979$ & Flat-V weir \\
Aire & Beal Weir & 27,003 & SE5304025471 & $01 / 1958$ & Broad-crested masonry weir \\
Wharfe & Tadcaster & 27,089 & SE4770644103 & $01 / 1991$ & Ultrasonic gauge \\
Ouse & Skelton & 27,009 & SE5684555373 & $09 / 1986$ & Ultrasonic gauge \\
Foss & Huntington & 27,083 & SE6123954337 & $04 / 1987$ & Electromagnetic gauge \\
Derwent & Buttercrambe & 27,041 & SE7311258712 & $01 / 1973$ & Crump weir with ultrasonics \\
Trent & North Muskham & 28,022 & SK80436056 & $09 / 1966$ & Ultrasonic gauge \\
Dyfi & Dyfi Bridge & 64,001 & SH744019 & $01 / 1962$ & Velocity-area \\
\hline
\end{tabular}




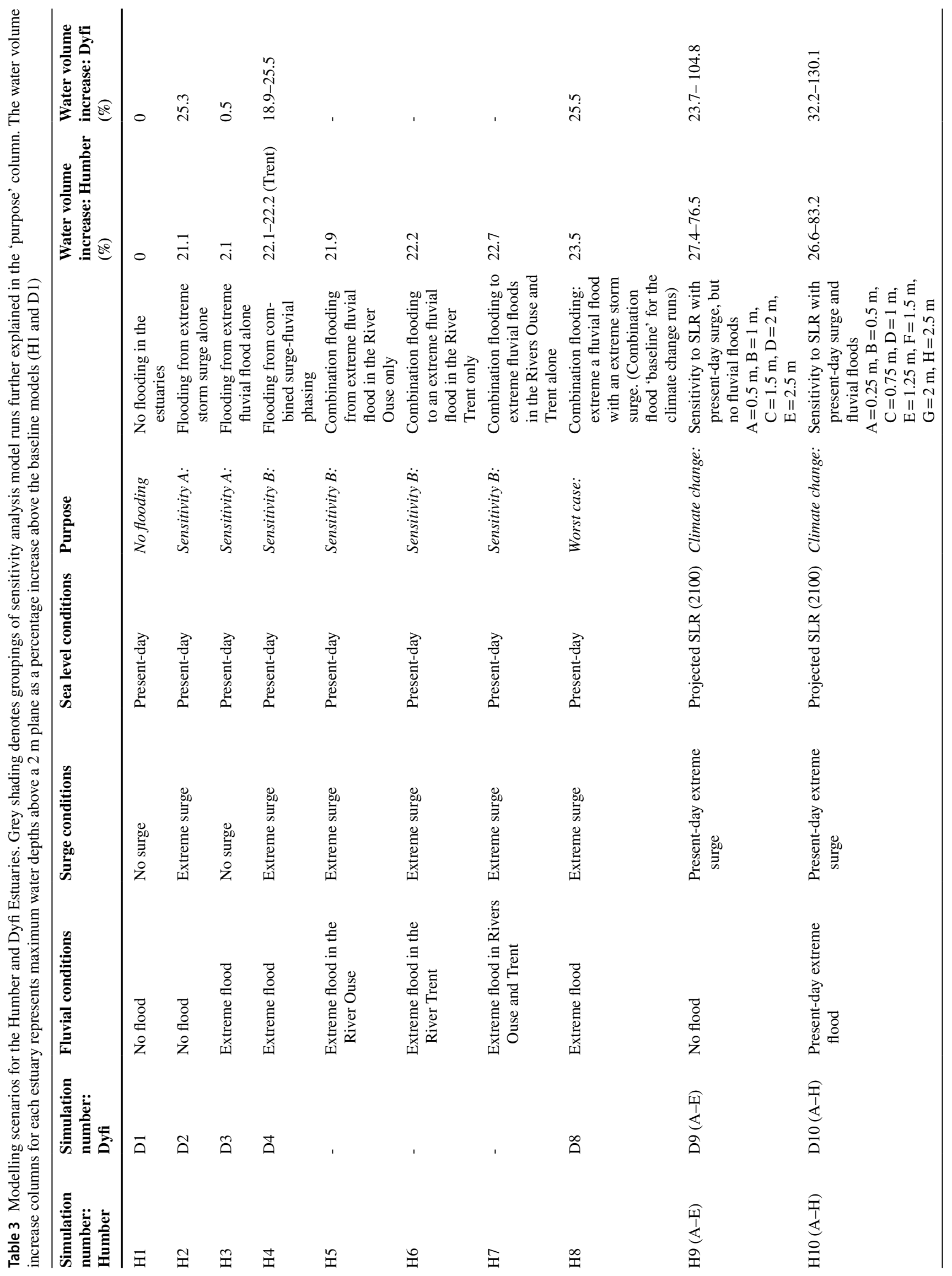




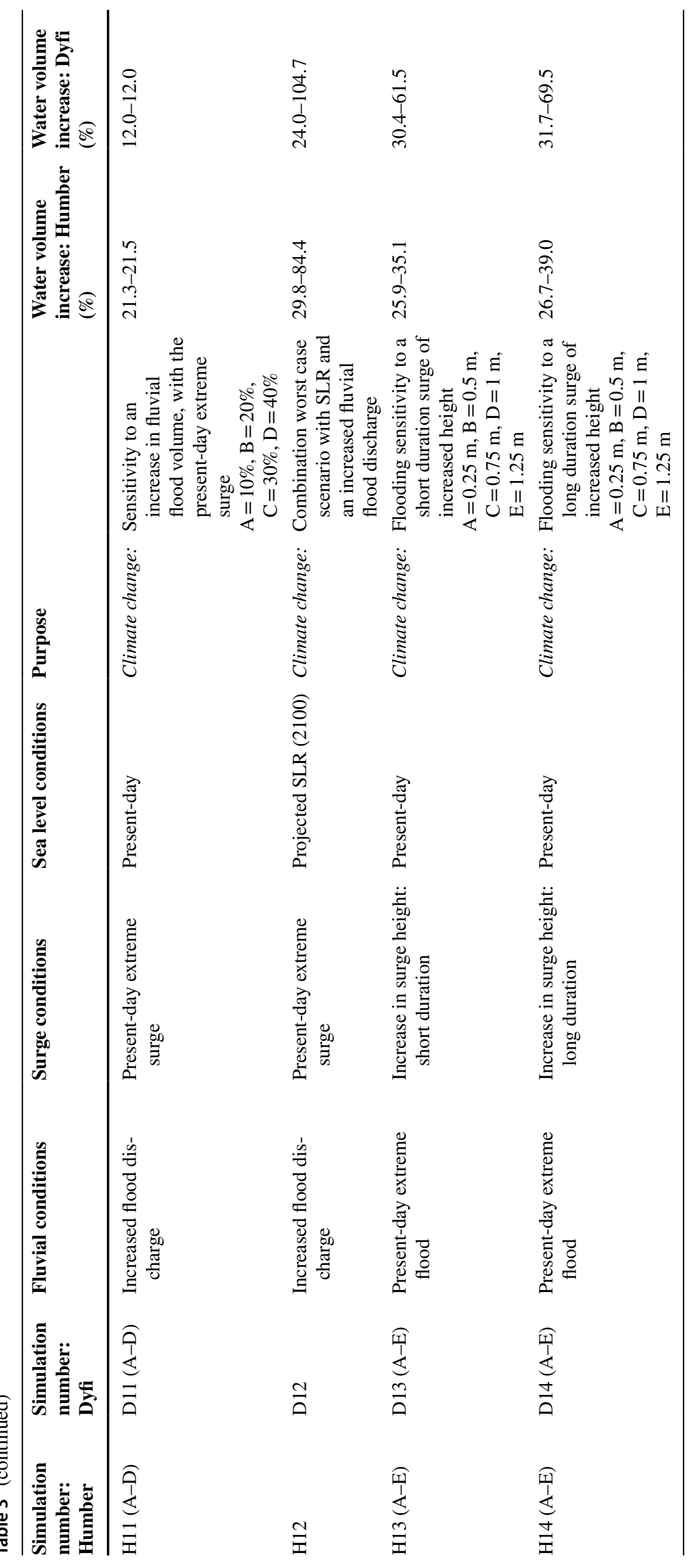


after the occurrence of the surge event, then every $2 \mathrm{~h}$ until $\mathrm{a} \pm 10$-h window was reached (run D4 in Table 3).

\section{Dyfi: Sensitivity Analysis on Tidal Elevations}

The Barmouth tidal gauge data (from 1991 to 2012) does not have a record of the largest surge occurring on a spring tide, as occurred on 05/12/2013 in the Humber. Although extreme skew surges around the majority of the UK (including Barmouth) are independent of high spring tides (Williams et al. 2016), the authors preferred to use an extreme event already in the present-day tidal records. Consequently, to simulate the worst-case surge tide on the Dyfi, three events were simulated (as preliminary runs): (1) the largest recorded surge (24/12/1997), with a skew surge of $1.48 \mathrm{~m}$, that occurred during neap tides resulting in a sea level of $2.78 \mathrm{~m} \mathrm{ODN}$; (2) the highest recorded sea level of $3.92 \mathrm{~m}$ ODN which occurred on 10/02/1997 (here, the skew surge was $0.73 \mathrm{~m}$ ); (3) a large surge (6th largest on record with a skew surge of $1.16 \mathrm{~m}$ ) which occurred at a high spring tide on 25/11/2000, resulting in a sea level of $3.71 \mathrm{~m} \mathrm{ODN} \mathrm{(3rd} \mathrm{highest} \mathrm{water}$ level recorded). More extensive flooding was simulated from the second (10/02/1997) and third (25/11/2000) events than the first (24/12/1997). As the skew surge was small on the second event, it was decided to use the third event for the worst-case flooding scenario hereafter.

\section{Climate Change Sensitivity Analysis}

Simulations incorporating sea-level rise (SLR) were carried out by adding incremental elevation to the surge-tide scenarios described above (runs H10 and D10 in Table 3). SLR was added in $5 \mathrm{~cm}$ increments up to $50 \mathrm{~cm}$, then in $50-\mathrm{cm}$ increments to $2.5 \mathrm{~m}$ which was the upper bound for SLR in both the Humber and Dyfi. SLR of $2.5 \mathrm{~m}$ is considered plausible but unlikely, although IPCC global SLR projections by 2100 do not exceed $0.98 \mathrm{~m}$ (Hoegh-Guldberg et al. 2018; Lowe et al. 2019), SLR up to $2 \mathrm{~m}$ is thought possible if rapid melting of polar ice sheets occurs (Nicholls and Cazenave 2010; Nicholls et al. 2011), with SLR continuing beyond 2100 .

The annual precipitation amount for the UK is not predicted to change by 2100 ; however, there is likely to be an increase in the clustering and intensity of storms especially in winter, leading to increased fluvial discharges, e.g. the exceptional storms during the winter of 2013/14 (Slingo et al. 2014; Hannaford 2015). Models project a potential $25 \%$ increase in fluvial discharges in the winter periods for the UK; however, there is much uncertainly around this estimate due to availability of precipitation data and catchment specific model downscaling (Robins et al. 2016). Therefore, to represent climate change to fluvial discharge, the magnitude of the present-day worst-case fluvial events (H11 and
D11 in Table 3) was increased incrementally by $10 \%, 20 \%$, $30 \%$ and $40 \%$. The future worst-case compound hazard simulations combined the SLR and increased fluvial discharge described above (H12 and D12 in Table 3).

Storm surges are caused by winds and air pressures acting on the sea surface (Pugh and Woodworth 2014). The magnitude of a surge is proportional to the wind-stress divided by the water depth, and surge height often increases with wind duration (Wolf 2009). Surge heights along the eastern North Sea and northwestern British Isles have been predicted to increase by $8-10 \%$ in the 99 th percentile between 2071 and 2100 (Debernard and Røed 2008). At Immingham tidal gauge, there has been a predicted increasing trend in surge heights by $+0.221 \mathrm{~m}$ in 50 years due to metrological forcing alone, but also an increased return period (Lowe et al. 2001). The present-day 500-year return period of a $+1.9 \mathrm{~m}$ extreme surge is reduced to 120 years accounting for future changes to metrological forcing alone, and just 12 years when also accounting for $0.5 \mathrm{~m}$ of SLR (Lowe et al. 2001). Different duration (long and short) surge types were modelled here (Fig. 2), as well as variable surge heights, to reflect natural variability with potential meteorological storm events and the possibility of increased surge heights around the UK with future climate change (Debernard and Røed 2008) (runs H13, H14, D13 and D14 in Table 3).

To simulate future extreme surges in the Humber (2013) and the Dyfi (2000), the present-day extreme surges were increased in $25 \mathrm{~cm}$ increments up to $1.25 \mathrm{~m}$. This provided a range of future extreme surge scenarios that have been compared with the present-day surge combined with SLR scenarios. The duration of the storm surge event was also modified so each height increment had two surge types, a long-duration (runs H14 and D14) and short-duration event (runs H13 and D13 in Table 3). Contrasting surge duration events were run to represent any differences in maximum water depths induced between a flashier surge event and a more prolonged event.

\section{Results}

\section{Present-Day Flooding: Sensitivity to Fluvial-Surge Phasing}

\section{Humber}

The difference between maximum water levels from the surge-only (H2) and surge combined with peak fluvial inputs (H8) is shown in Fig. 3. As anticipated, with increased fluvial discharges Fig. 3 shows elevated maximum water levels (up to $60 \mathrm{~cm}$ ) in the inner estuary, but a less intuitive result was a slight decrease in water levels $(\sim 1 \mathrm{~cm})$ in the outer estuary. The fluvial-surge phasing 
Fig. 2 Schematic of tidal and different storm surge events used for the storm surge climate change scenarios (models H13-14 and D13-14). Both long-duration surge (blue line) and short-duration surge (green line) are shown in comparison with the present-day surge (orange line) and the astronomical tide (black line)

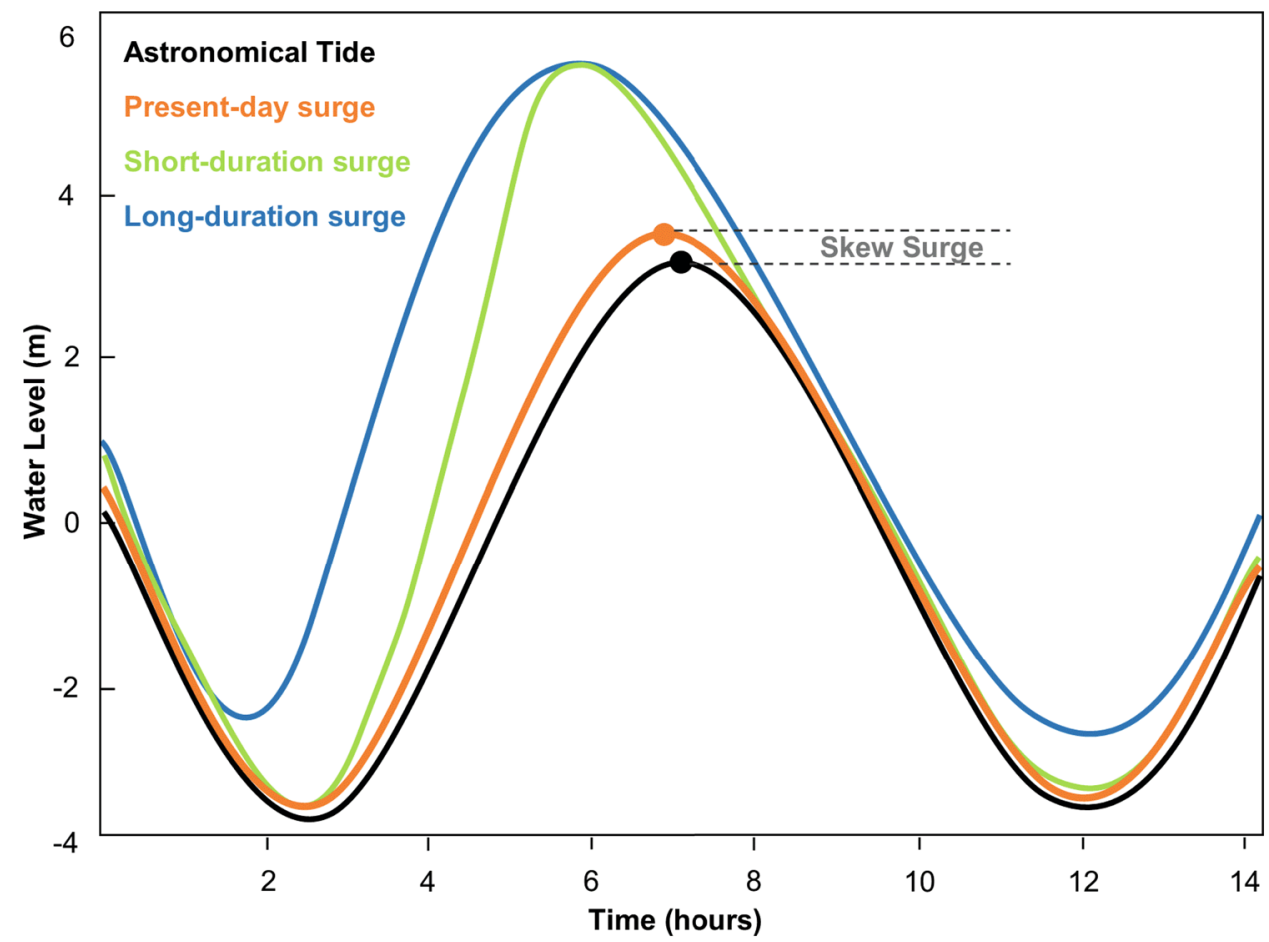

had little effect on maximum water levels in the lower estuary, due to the large volume of the estuary. However, altering the fluvial inputs of the major rivers (Ouse and
Trent) had a clear impact on water levels in the upper estuary (Fig. 4). Figure 4 shows the maximum water levels along the central axis of the estuary for different
Fig. 3 Worst-case flood in all rivers of the Humber estuary (run 8). DEM of difference shows maximum water elevation difference between surge only and worst-case scenarios

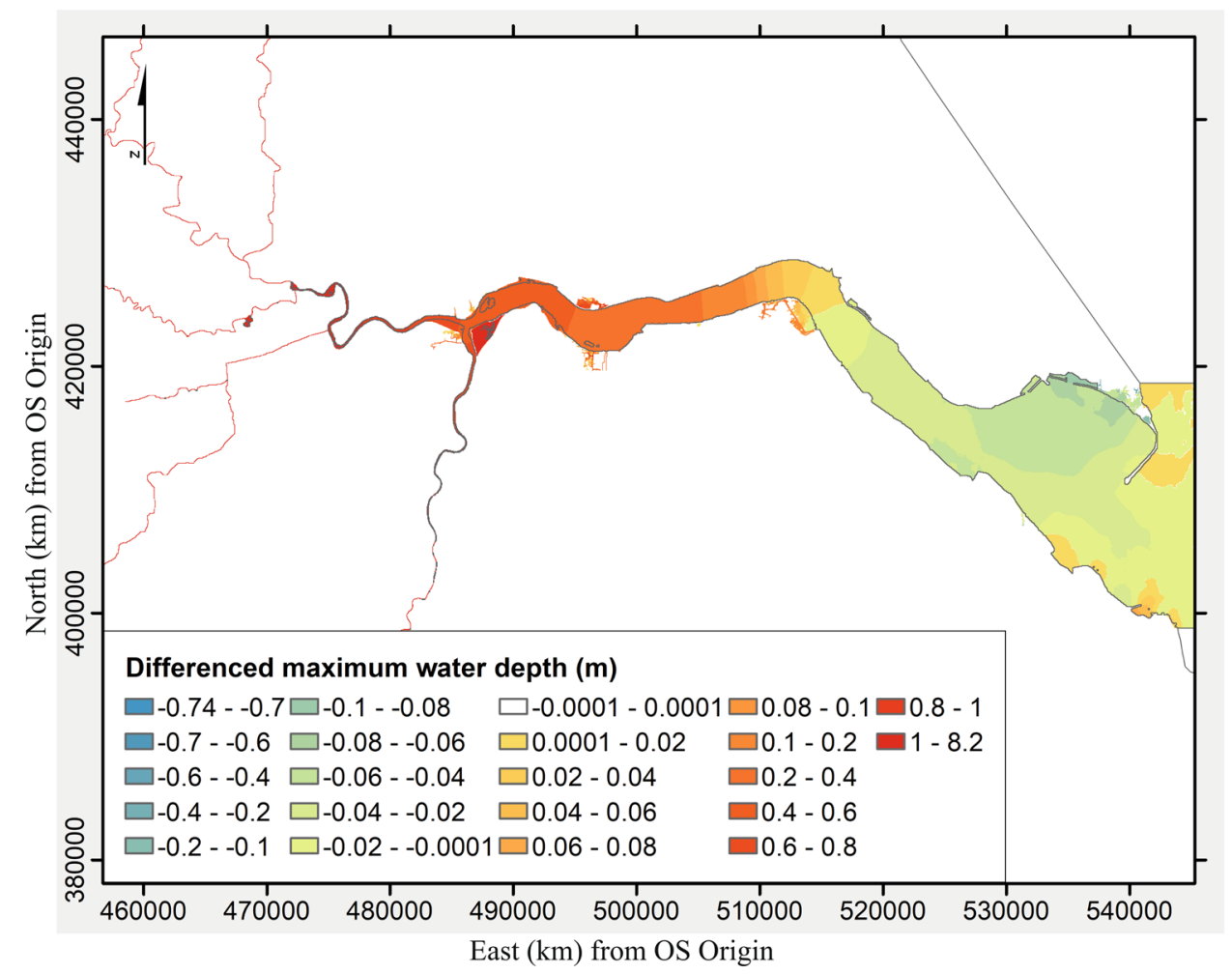


Fig. 4 Humber maximum water surface elevations along the estuary long profile. Model runs show flooding from an extreme storm surge alone (H2), compound flooding from extreme fluvial flood in the River Ouse only (H5), the River Trent only (H6), Rivers Ouse and Trent only (H7) and the worst-case scenario combining the storm surge and flooding in all rivers (H8)

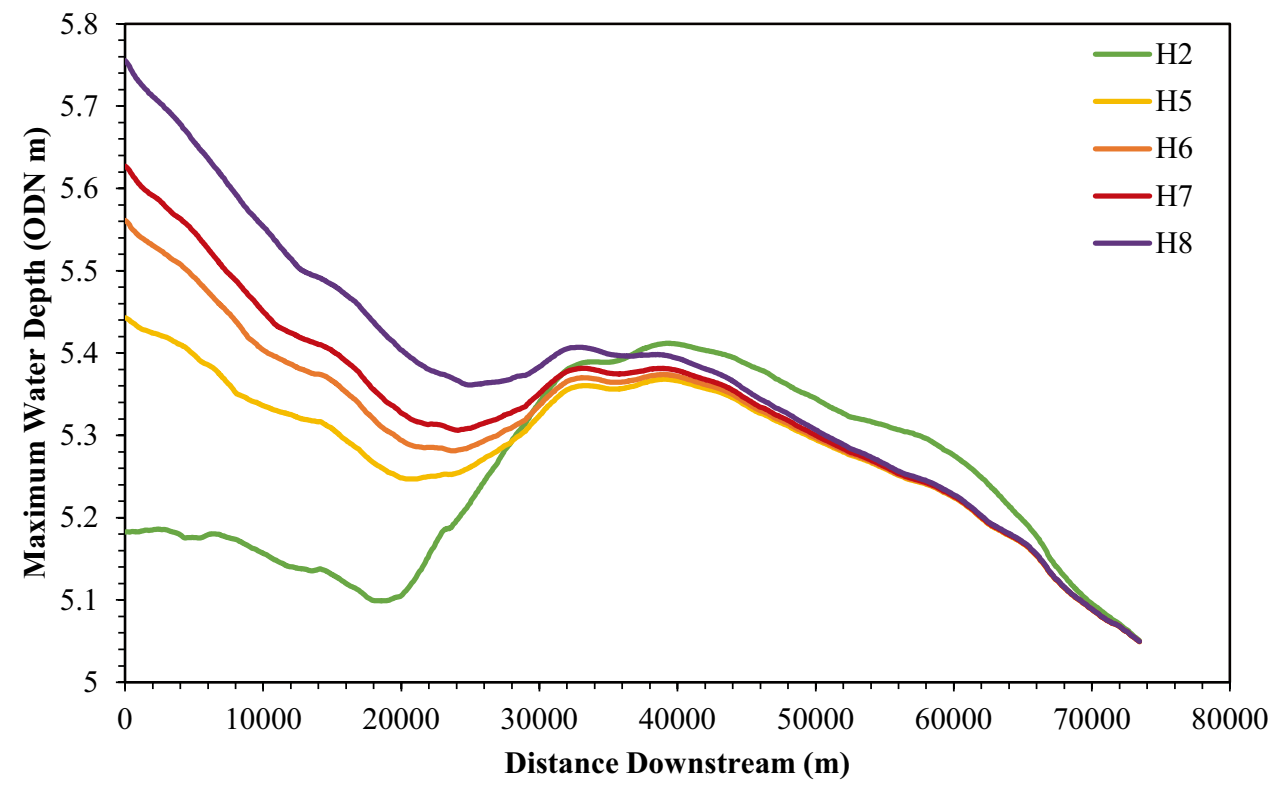

scenarios, demonstrating the co-occurrence of high surge with fluvial floods in the Ouse, Trent and/or all tributaries (runs H5-H8) increases inner estuary water depths from the surge-only scenario (H2). Figure 4 also demonstrates the water level reduction in the outer estuary, for the four fluvial-surge co-occurrence scenarios compared with the surge-only scenario. Interestingly, adding a large flood in the Ouse only (mean discharges in other rivers) combined with a surge, reduced water depths in the outer estuary more so than the other fluvial-surge scenarios, which had a larger volume discharge into the estuary, likely the result of a reduced pressure gradient force (head driven flow), which is discussed further in the section 'Which are the most significant changes in drivers for flooding?'.

\section{Dyfi}

Fluvial-surge phasing (D4) exerted a greater influence on water levels and flooding in the Dyfi than simulated in the Humber. Figure 5 a illustrates that when the 1979 fluvial flood arrived $10 \mathrm{~h}$ before the surge, water depths throughout the estuary were increased from the surge-only (D2) scenario. However, the largest flood extent and depths were simulated when the fluvial peak occurred 45 min before the

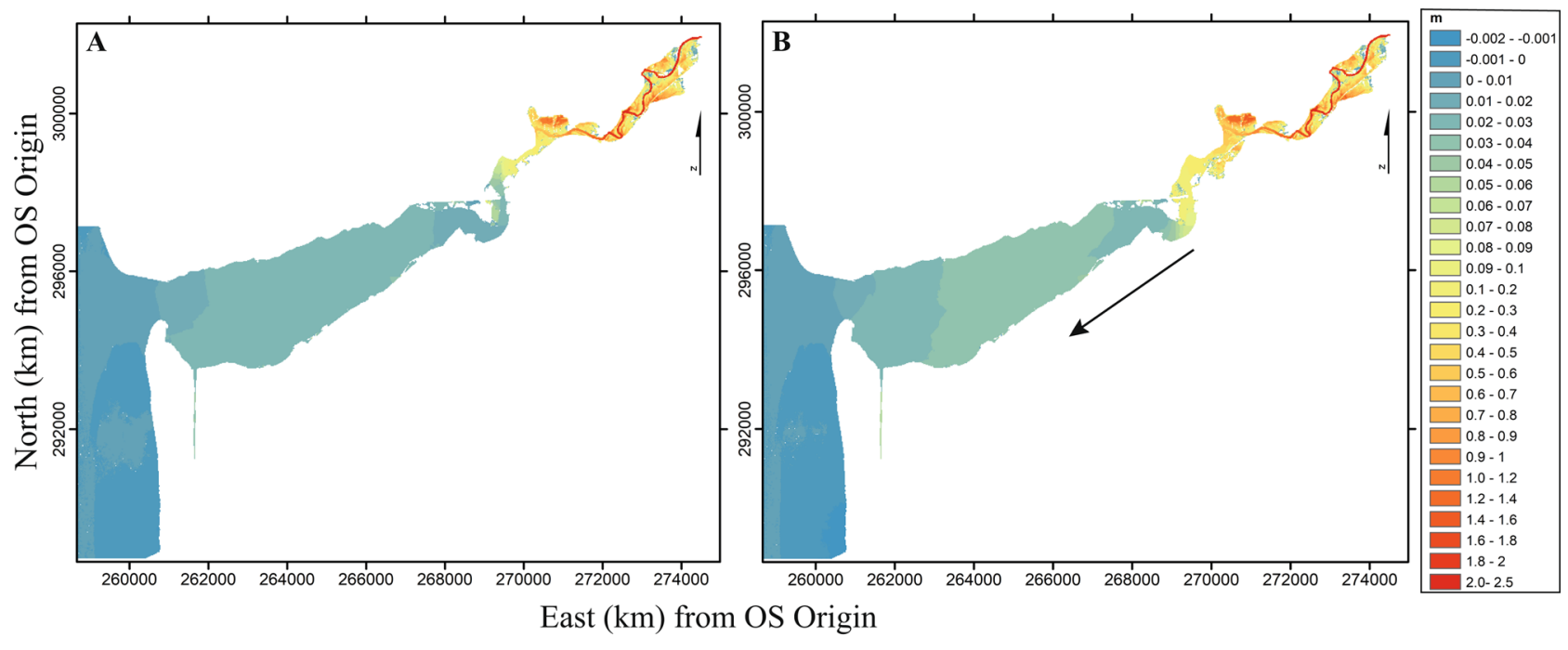

Fig. 5 Dyfi estuary worst-case fluvial-surge scenarios differenced from surge-only scenario. The 1979 flood peak was timed at (A) $-10 \mathrm{~h}$ and $(\mathbf{B})-0.75 \mathrm{~h}$ before the arrival of a storm surge (run
D4). The arrow demonstrates the movement of the fluvial flood water further downstream into the estuary from -10 to $-0.75 \mathrm{~h}$ 
surge (Fig. 5b). In the upstream fluvial region of the Dyfi, overbank flooding occurred in all simulations including the 1979 flood; however, the extent varied depending on fluvialsurge phasing. Maximum water level profiles along the central axis of the estuary (Fig. 6) further illustrate this - and in contrast to the Humber, there is no change in outer estuary max water elevations.

\section{Climate Change Flooding Sensitivity}

Humber. Increasing the fluvial discharge (up to $+40 \%$; run 11), in compound with the unaltered 2013 surge, increased water levels in the inner estuary but not in the outer estuary (Fig. 7a) compared with $\mathrm{H} 2$ (present-day). This result demonstrates the 'backwater' effect hazard to the inner estuary from fluvial water that is unable to be advected downstream/ offshore. When adding in SLR $<1 \mathrm{~m}$ (runs H9 A-E and H10 A-H), the 'tipping-point' between increased and decreased water levels does not shift upstream compared with the present-day scenarios (H2 and H8). However, when SLR $>1 \mathrm{~m}$, the flood defence barriers were overtopped (H10 D-H) and the tipping-point shifted downstream towards the outer estuary (black arrows in Fig. 7b).

We tested the impact of increasing the maximum 2013 surge height by simulating: (1) a short and sharp increased surge peak (short-duration surge, H13); and (2) a smoother increase over time in a surge peak (long-duration surge; H14)—see Fig. 8. There was a noticeable difference in maximum water elevation; the long-duration surge resulted in higher maximum water depths throughout the estuary than the short-duration surge peak, due to the difference in total water volume: therefore storm surges with the same height may have very different volumes (due to duration), which was found to be important in estuarine response. This pattern was exaggerated for larger magnitude surge events. The short-duration surge peak resulted in less water flux into the estuary than a long-duration surge peak despite the surge height being the same, due to the rapid increase in estuary width and the resulting dissipation of surge height and lower overall water flux. However, the long-duration surge saw higher water depths offshore of Spurn Point indicating the blocking effect of Spurn Point.

The simulated future worst-case compound hazard with SLR exceeding $+0.75 \mathrm{~m}(\mathrm{H} 10 \mathrm{C}-\mathrm{H})$, resulted in overtopping of the flood defences and railway infrastructure causing significantly more overbank flooding than the present-day scenarios. SLR less than $+0.75 \mathrm{~m}$ did not cause overtopping. With $>2 \mathrm{~m} \mathrm{SLR}$, the whole of the city of Hull and towns along the estuary on the south bank of the estuary were simulated to flood (H10 G).

Potential future flooding, as a result of surge-only scenarios but with increased surge height (using the long-duration surge; H14) were compared with the SLR (H10) scenarios of the same water level height (e.g. $+1 \mathrm{~m}$ surge compared with $+1 \mathrm{~m} \mathrm{SLR}$ ). Figures 9 and 10 show that an increased surge height of $+1 \mathrm{~m}$ increased the maximum water levels in the outer estuary and overtopped flood defences on the northern bank, whereas the $+1 \mathrm{~m}$ SLR scenario did not. However, for the surge scenario, maximum water levels were reduced in the inner estuary and overbank flooding was reduced along the southern bank in comparison with the SLR scenario.
Fig. 6 Dyfi maximum water surface elevations along the estuary long profile. Model runs show normal conditions under no flooding (D1), an extreme storm surge alone (D2), an extreme fluvial flood alone (D3) and the worst-case compound of surge and fluvial flood (D8)

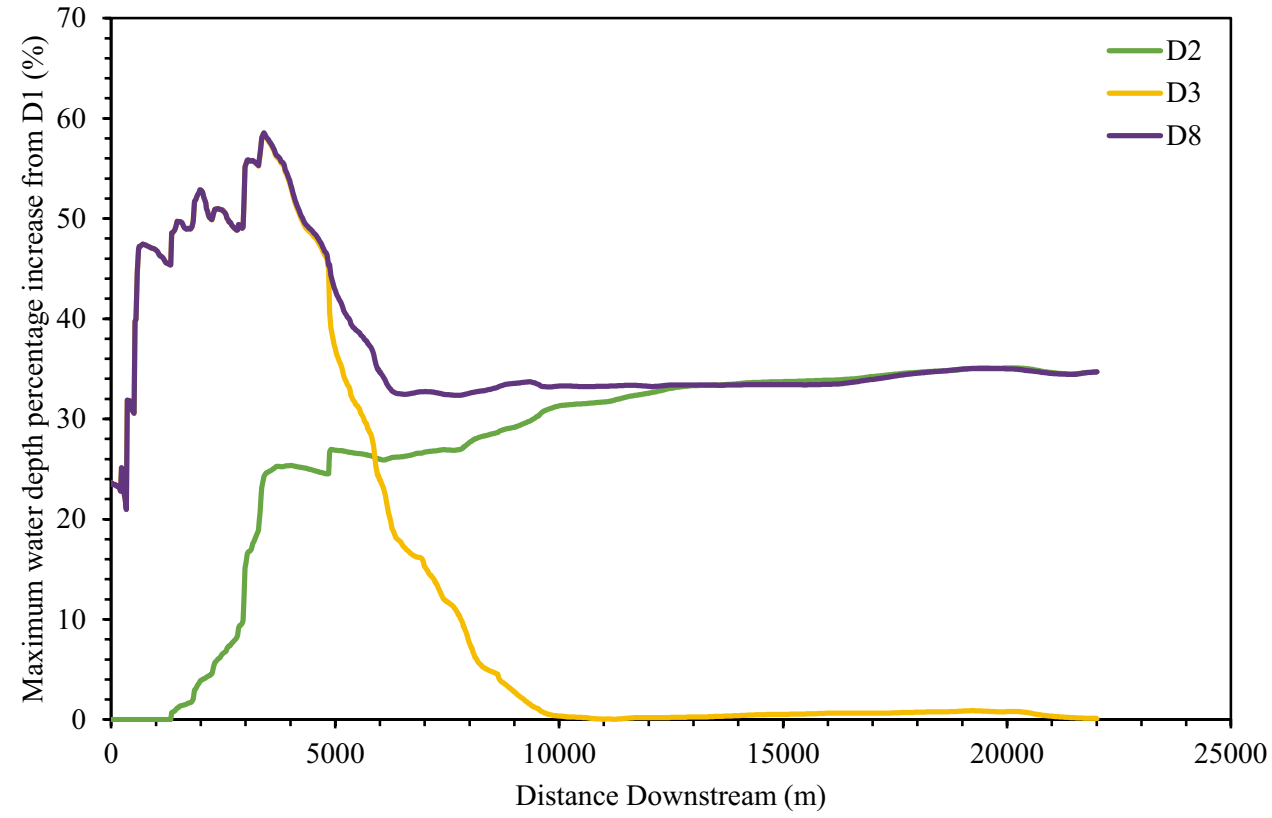


Fig. 7 Humber: along-estuary profiles of maximum water elevations. A Increased fluvial flood volume (greyscale lines; Climate change runs H11 A-D), compared with the present-day worst-case compound event (H8) and surge only event (H2) (blue lines). B Compound event of surge and fluvial flood with SLR (solid colour lines; Climate change H10 A-H), compared with surge only events with SLR (dashed colour lines; Climate change H9 A-E). The present-day worst-case (H8) and surge-only (H2) scenarios are also shown for comparison (blue lines). Black arrows show the location along the profile of the 'tipping-point' between increased and decreased water levels. See Table 3 for model run explanations
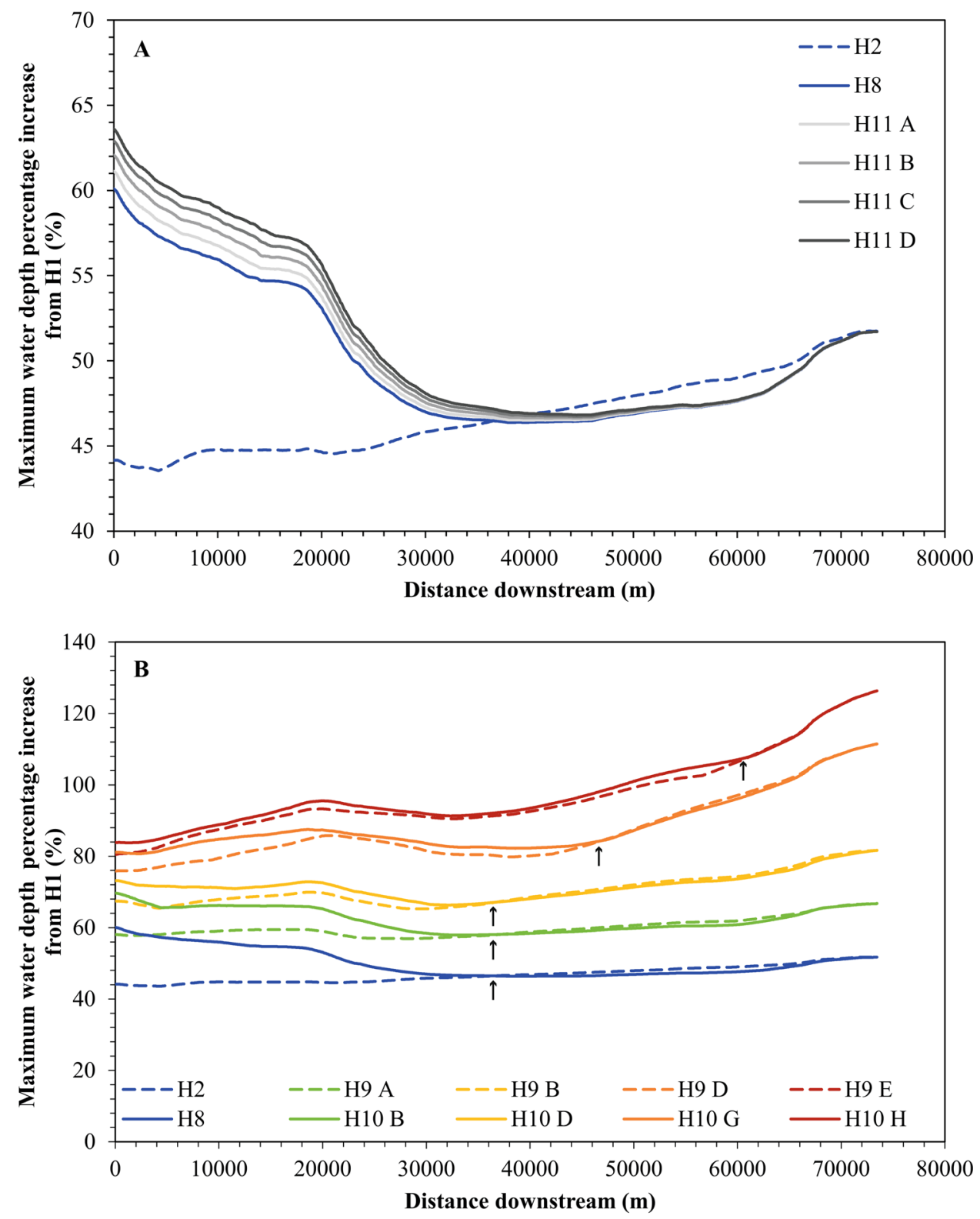

Dyfi. Increasing the fluvial discharge ( $\geq 10 \%$; runs D11 A-D) above the present-day extreme (D8) increased maximum water depths throughout the estuary (Fig. 11) but did not increase the spatial extent of flooding. The present-day worstcase scenario (fluvial and surge-tide events; D8) was run with incremental increases in surge height (up to $+1.25 \mathrm{~m}$ ). Models were run with both the short-duration surge (D13) and a long-duration surge (D14). The long-duration surge resulted in higher water depths than the short-duration surge, for each case (Fig. 12). For surge heights greater than $+1 \mathrm{~m}$, there was a drop in maximum water levels at the Dovey Junction bridge ( $\sim 10 \mathrm{~km}$ downstream in Fig. 12), which constricts the available width and height of water upstream for the sudden influx of surge water.
SLR greater than $+0.75 \mathrm{~m}(\mathrm{D} 10 \mathrm{C}-\mathrm{H})$ resulted in overtopping of the flood defences mostly along the southern bank, with more extensive spatial flooding with greater SLR, including flood depths in the fluvial region up to the town of Machynlleth.

Future surge-only scenarios (with surge heights increased incrementally up to $+1.25 \mathrm{~m}, \mathrm{D} 13$ and D14) resulted in a reduction in maximum water levels when compared with the SLR-only scenarios of the same heights (D10) (Fig. 13). This behaviour was comparable with that simulated in the Humber. When the surge height was increased above $+0.5 \mathrm{~m}$ (D14), the maximum water levels in the fluvial region and upper estuary increased above those of the SLR-only scenarios of the same heights 
Fig. 8 Humber: along-estuary profiles of maximum water depths showing the difference between short-duration (dashed lines, H13 A-E) and longduration (solid lines, H14 A-E) storm surges

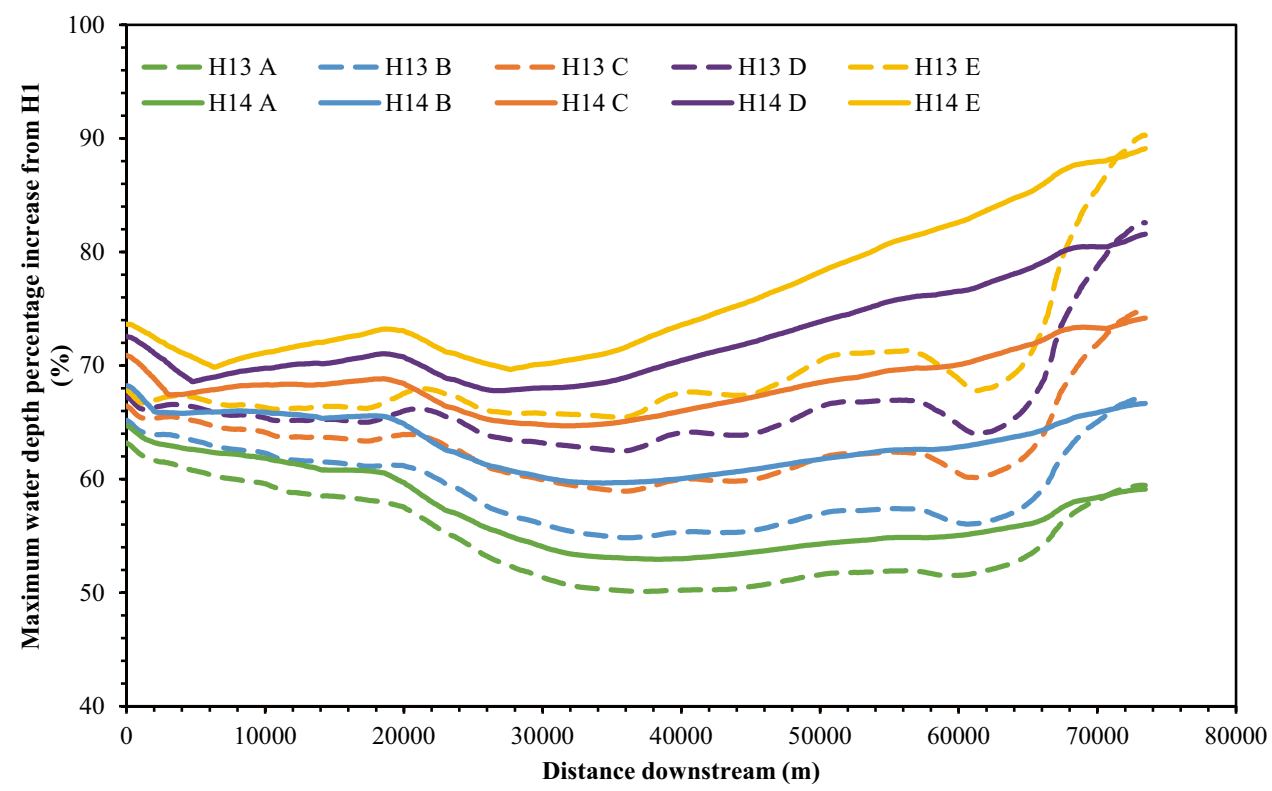

(D10). An increased surge of $+1 \mathrm{~m}$ increased water levels in the upper estuary but reduced the amount of overbank fluvial flooding compared with $+1 \mathrm{~m}$ SLR scenario. A further increase of surge height (beyond $+1.25 \mathrm{~m}$ ) reduced maximum water depths at the estuary mouth as well as upstream of Dovey Junction bridge.

\section{Discussion}

\section{Compound Flooding from Fluvial and Surge Events}

Our findings clearly show that the sensitivity of flooding to the relative timings of fluvial and surge-tide extremes
Fig. 9 Humber: difference in maximum water depths from a $1 \mathrm{~m}$ increase in long-duration storm surge height (H14 D) differenced from the present-day extreme surge with $1 \mathrm{~m}$ of SLR (H10 D)

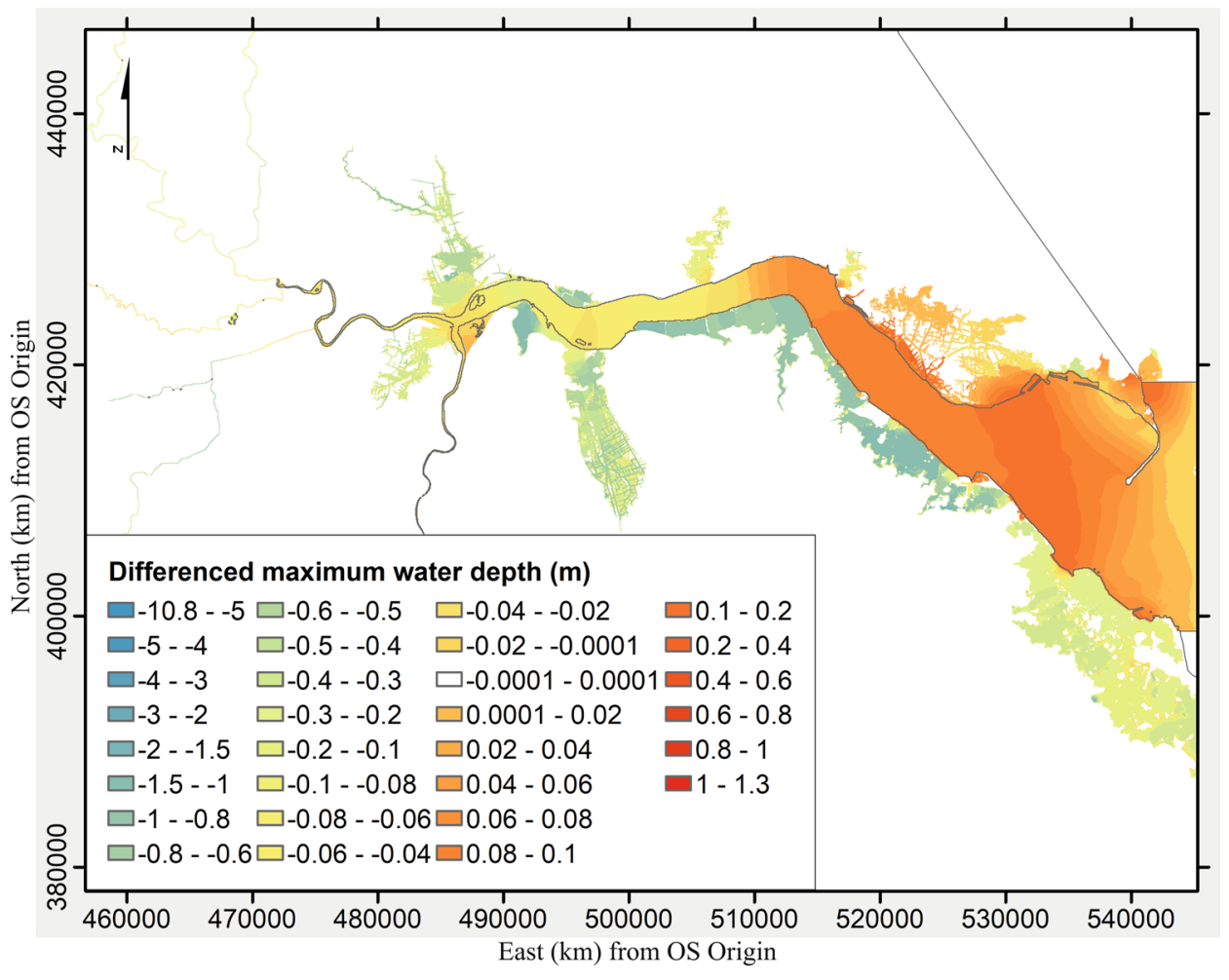


Fig. 10 Humber: along-estuary profiles showing the difference of maximum water elevations between increases in sea level rise (solid lines, H10 A-E) and long-duration storm surge (dashed line, H14 A-E)

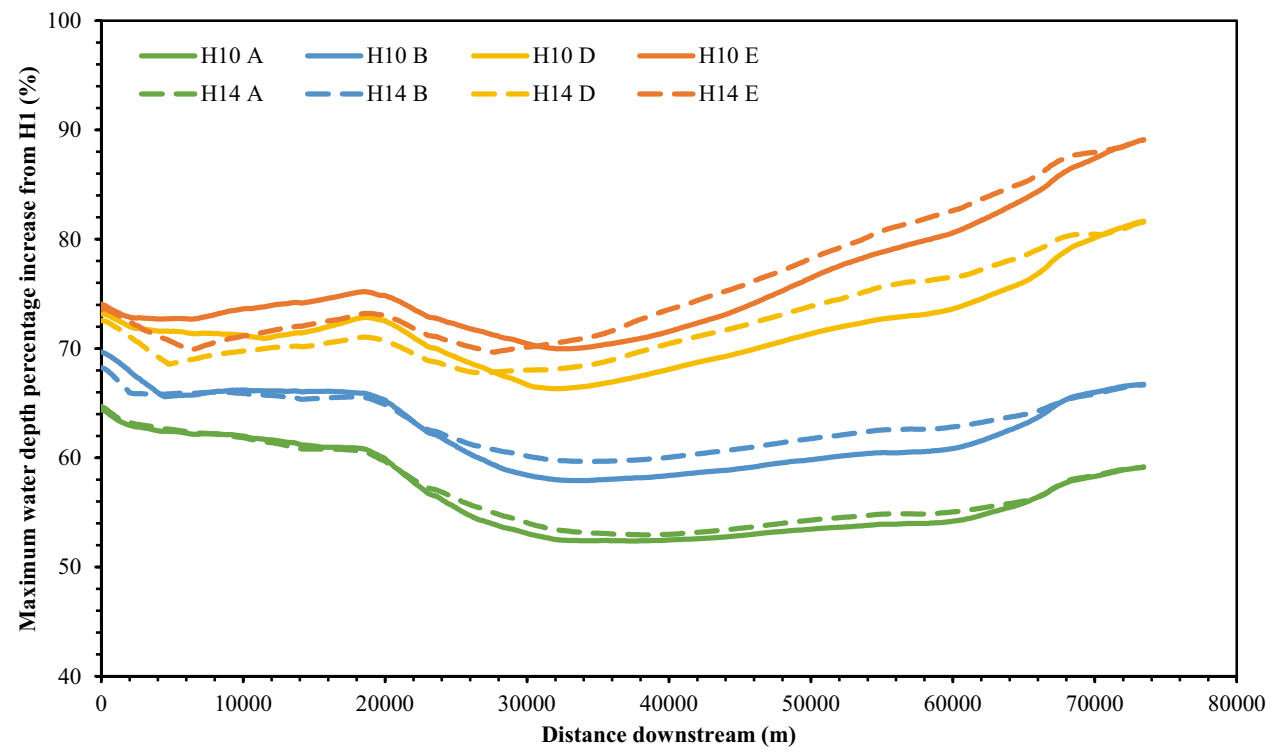

was contingent on the size of the estuary. For the larger Humber, flood depth was greatest when peak fluvial discharge at the gauging stations was timed $3 \mathrm{~h}$ before a high surge-tide, although in effect, the relative timings were not important (H4). However, for the smaller Dyfi, flood extent and depth were sensitive to these timings-being greatest when peak fluvial discharge arrived 45 min before high surge-tide (run D4, Figs. 4 and 6). This agrees with the findings of Robins et al. (2018) for the Humber, who described the system as 'slow response' due to the slow river response to rainfall since the catchment is large and of shallow gradient, and the large estuary volume being less sensitive to fluctuations in river discharge. The hydrograph for the November 2000 storm lasted 11 days, which was soon followed by another large storm which lasted
12 days. This means that our fluvial-surge timing sensitivity window of $\pm 12 \mathrm{~h}$ (run $\mathrm{H} 4$ ) would not have produced a large difference in discharge.

In the Dyfi, extensive flooding occurred in the upper estuary in all fluvial-surge phasing scenarios (D4). It was only further downstream in the mid/lower estuary that flood timing relative to surge markedly affected flood depths (Maskell et al. 2014), e.g. whether overtopping of embankments near Dovey Junction occurred. Fluvial flood waters propagated downstream and increased water levels near the estuary mouth in all fluvial-surge scenarios, a behaviour which differs from the Humber but concurs with studies in the similar sized Conwy by Robins et al. (2018). The hydrograph for the Dyfi during the 1979 storm is much flashier than for the Humber, due to the shorter and steeper catchment
Fig. 11 Dyfi: along-estuary profile of maximum water depths, for the increased fluvial flood volume combined with the present-day extreme surge (greyscale, climate change scenario D11 A-D), in comparison with the present-day worstcase compound event (solid blue, D8) and surge only event (dashed blue, D2)

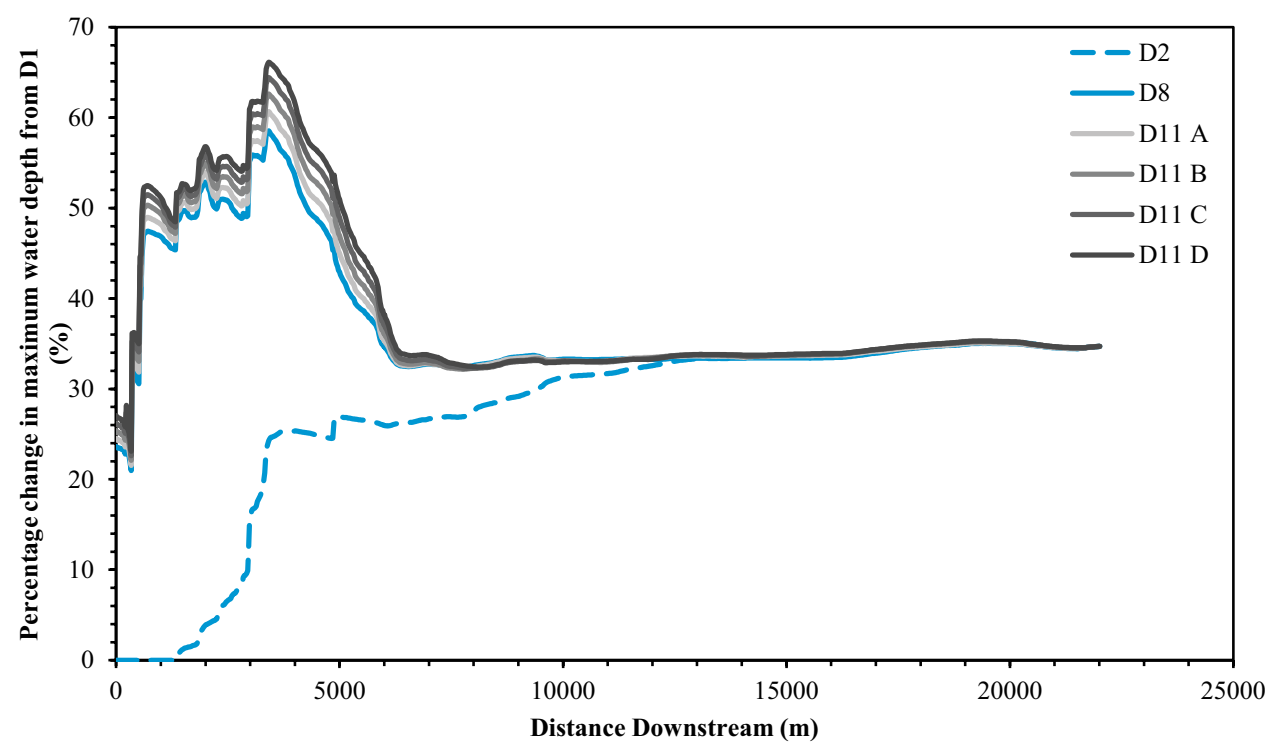


Fig. 12 Dyfi: along-estuary profile of maximum water depths of short-duration (dashed lines, D13 A-F) and long-duration (solid lines, D14 A-F) storm surges. The black arrow denotes the approximate location downstream of the Dovey Junction rail bridge constriction

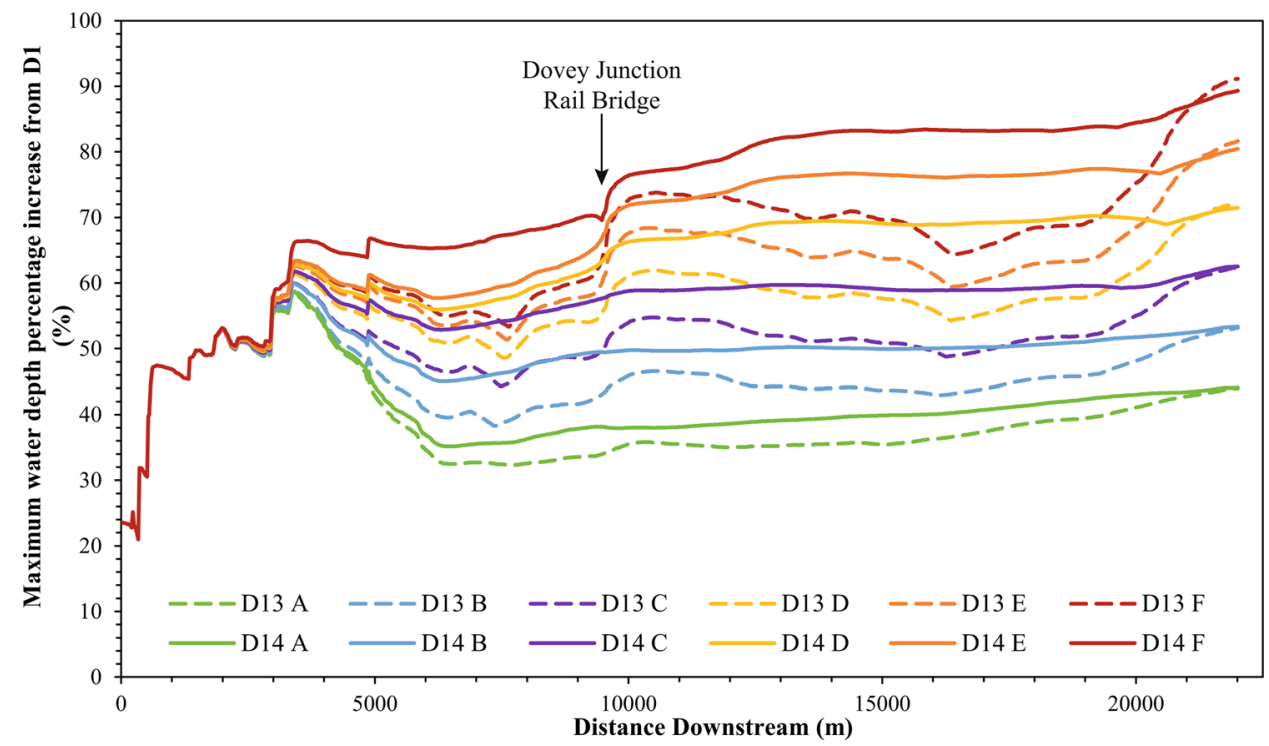

topography, resulting in a storm duration lasting around $8 \mathrm{~h}$. We therefore find a greater difference in flood discharge within the \pm 10 -h phasing sensitivity window (run D4). As such, the relative timing of fluvial and surge-tide interactions during a compound event in a fast-responding catchment has a large impact on overbank flooding spatially.

In the Humber, there are multiple large fluvial inputs, which dictate the response of the upper and middle estuary. However, the downstream extent of the fluvial response is limited and shifts up/downstream depending on which rivers are flooded, which is realistic given the spatial distribution of rainfall over such a large catchment area, or the delay in discharge due to snow melt (for example, the
March 1947 extreme flood where the Trent peaked a week before the Ouse (RMS 2007)). High discharge in several of the Humber rivers (run H8), or in just the Trent (run H6), caused the greatest flood depths. High discharge in all the rivers in unison (H8) had the largest implications for flooding of the city of Hull, and importantly, the River Hull flood defence barrier. However, a perhaps counter-intuitive result was that a compound hazard of high fluvial and surge-tide (H8) slightly reduces water depths in the outer estuary from that of a surge alone event (H2). This interaction between flood drivers is a key component of determining flood risk which cannot be discerned by either probabilistic flood risk analysis or modelling using the 'bathtub' approach. This
Fig. 13 Dyfi: along-estuary profiles of maximum water depths showing future SLR-only (solid lines, D10 A-F) compared with long-duration surge-only scenarios (dashed lines, D14 A-F)

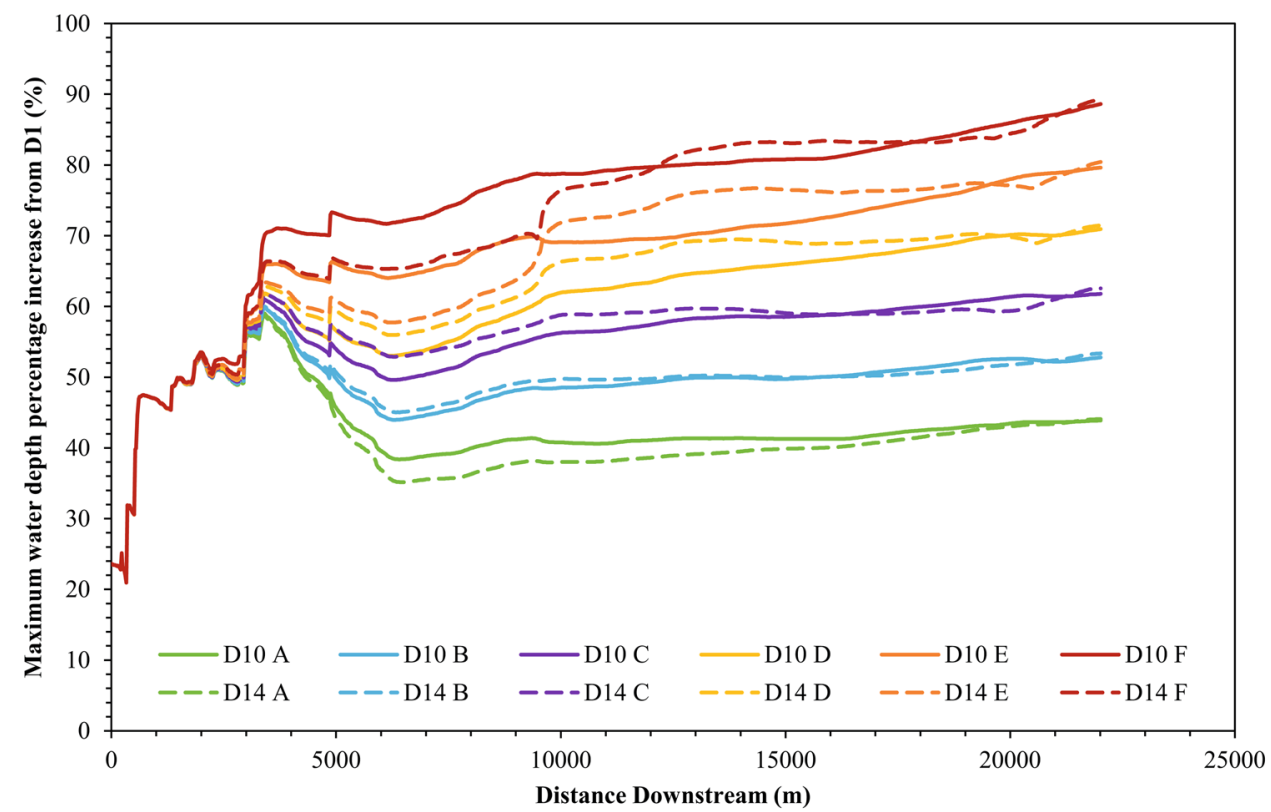


result may be due to high fluvial discharge over numerous days, which opposes the inflowing force of the storm surge (e.g. Orton et al. 2018).

For the Humber estuary, Spurn Point does not seem to effectively block a storm surge entering the estuary but appears to impede water leaving the estuary, instead causing a bottleneck amplifying flood waters. Lyddon et al. (2018) showed there was a funnelling effect verses a frictional effect for a large funnel type UK estuary (Severn), which may also be occurring in the Humber. Figure 4 shows that a surge-alone event $(\mathrm{H} 2)$ results in higher maximum water depths in the outer estuary which increases with distance up-estuary until maximum water depths peak near to Paull (c. 40,000 m downstream), after which maximum water depths reduce. This increase of maximum water depths with distance upstream could be a result of the funnelling effect of the estuary shape, and frictional forces become stronger upstream of Paull where there is a topographical bend in the estuary and further narrowing, resulting in tidal damping. During a compound event, the opposing force of fluvial flood waters increases the resistance to an incoming storm surge increasing the tidal damping effect.

For the worst-case fluvial-surge event in the Dyfi (D8), the compound hazard increased water depths slightly across the whole estuary, but fluvial flood impacts were mostly constrained to the upper estuary. The dominance of fluvial extremes in the Dyfi estuary could be due to its smaller size or the difference in estuary shape. Both estuaries are funnel shaped, however the Dyfi is a bar-enclosed ria (Pye and Blott 2014) resulting in the width of the mouth being approximately $28 \%$ of the maximum width, compared with approximately $52 \%$ in the Humber. The Dyfi contains a channel (c. $11 \mathrm{~m}$ deep) at the estuary mouth which rapidly shallows in the outer estuary (Brown and Davies 2010), in contrast with the Humber which maintains channels $(>10 \mathrm{~m}$ deep) throughout the estuary. The dominance of fluvial extremes in the Dyfi could be the result of the estuary morphology; the barrier obstructing a storm surge propagating into the estuary, together with a rapid increase in estuary width and decrease in depth leading to increased frictional resistance and tidal damping (e.g. Lyddon et al. 2018). When a storm surge is combined with fluvial flooding, fluvial flooding has a greater impact of increasing tidal resistance, and also reducing the salinity in smaller estuaries such as the Dyfi, due to the greater river to estuary volume than in larger estuaries (Robins et al. 2018).

\section{The Effect of Increased Fluvial Discharge}

For both estuaries, the least important driver for future flooding was increased fluvial discharge (both peak and volume increase of +10 to $+40 \%$ ) with the present-day surge (runs H11 and D11). This is because fluvial impacts were confined mainly to the upper estuaries. However, these fluvial changes are vital to include in future simulations as they affected the overall spatial distribution of flooding (e.g. Kumbier et al. 2018). Increased fluvial flooding in the Humber resulted in a small increase in flood depths in the upper and middle estuary but had no impact in the outer estuary. In other words, we predicted a tipping point within the estuary beyond which changes in fluvial discharge did not have an effect. However, when these scenarios were compound with $>1$ m SLR (H12), the tipping point propagated downstream towards the outer estuary meaning that fluvial waters increased flood extent. For the Dyfi, maximum water depths throughout the estuary were slightly increased for a $20 \%$ increase in fluvial discharge (D11 B), but more so in the inner estuary. A limiting factor in the propagation of flood waters downstream could be the constriction near the estuary mouth (Fig. 1), causing a potential bottleneck for the fluvial water. There is likely a greater sensitivity of flooding from changing fluvial discharge in the Dyfi than the Humber, since flooding in the outer Humber did not markedly change even with a $40 \%$ increase in discharge (H11 D).

\section{The Effect of Increased Storm Surge}

An increase in surge height was shown to be a key driver of increased flood depths, compared with an increase in fluvial discharge - for both estuary types (runs H13, H14, D13 and D14 in Table 3). A similar result was shown by Maskell et al. (2014) for an idealised estuary. When comparing maximum water depths from both short-duration and long-duration events of the same surge height, longduration event resulted in higher maximum water levelsfor both estuaries, particularly in the outer estuary regions (Figs. 4b and 5b). Indeed, sensitivity to the duration of the total surge volume, rather than just the skew surge height, was the most important driver of the worst-case flooding-irrespective of estuarine shape (Figs. $4 \mathrm{~b}$ and 5b). Both estuaries have constrictions at the mouth, resulting in the spreading of the surge once propagated in-estuary and a reduction in water level. As the surge wave propagates upestuary, the narrowing in width (common in all estuaries) results in a funnelling effect, which generates an increase in the surge height (e.g. Lyddon et al. 2018). In the upper estuary, whether the surge was short- (H13, D13) or longduration $(\mathrm{H} 14, \mathrm{D} 14)$ had minimal effect on water levels. In the Dyfi, the 'bottleneck' effect of the Dovey Junction bridge restricted surge propagation causing a sharp drop in maximum water level beyond the constriction (see Fig. 12). 


\section{The Effect of Sea-Level Rise}

SLR was the most dominant climate change driver of flood extent in both the Humber and the Dyfi since most flood defences were overtopped with SLR of $0.75 \mathrm{~m}$ (equivalent to IPCC 2018 Representative Concentration Pathway (RCP) scenario 8.5) (runs H10 and D10 C-H). In the Humber, there is low topography and little restriction of the spread of flood waters until $\sim 43 \mathrm{~km}$ up-estuary from the mouth. This pattern is not seen in the Dyfi even though the flood defences were overtopped with $0.75 \mathrm{~m} \mathrm{SLR}$, because the estuary sits in a valley surrounded by steep hillslopes limiting the lateral spread of floodwaters.

The simulated estuary flooding from either SLR or surge of the same height were not the same. The surge + SLR scenarios (H10, D10) in both estuaries resulted in an increased area of total flooding, whereas surge-only scenarios of the same total height (H13-14, D13-14) caused less overbank flooding, but higher maximum water depths within the estuaries (Figs. 9, 10 and 13). This suggests that changes in surge patterns cannot be represented by simply increasing water levels, instead requiring the surge behaviour to be considered. The differences in flood behaviour may be explained by the higher base water level of the surge + SLR scenarios, meaning the estuaries were less able to absorb the impacts of a surge when it arrived. This behaviour was exacerbated in the scenarios with higher SLR due to the astronomical tidal cycle, meaning a renewed influx of water overtopping flood defences every high tide.

\section{Which Are the Most Significant Changes in Drivers for Flooding?}

In the Humber, there was an unexpected flooding response from the compound fluvial and surge events (H8), in comparison with the surge-only events $(\mathrm{H} 2)$, creating a clear tipping-point in the mid-estuary: upstream of which the fluvial discharge added to the flooding as one might expect, but downstream of which flood levels were reduced-i.e. the surge effect on water levels was reduced when combined with high fluvial discharges showing the complex interactions of compound hazard drivers (Kappes et al. 2012). It is hypothesised that the fluvial discharge reduces the head in the estuary (i.e. pressure gradient force) and thus capacity of a storm surge to enter into the estuary aided in part by the constriction at the mouth of estuary. The position of the tipping-point was found to be dependent on flood magnitude-shifting seawards with large fluvial extremes associated with the climate scenarios (H10, H12).

The Dyfi was also sensitive to fluvial-surge phasing during a compound event due to the flashy hydrograph and small estuary area which impinges on maximum water depths. While fluvial-surge scenarios (run D4) markedly increased maximum water depths the inner estuary, above the levels from the surge-only scenario (run D2), fluvial waters increased water depths throughout the estuary-i.e. the tipping-point found in the Humber was not simulated in the Dyfi, which may be because of the different ratios of fluvial flood volume to estuary area.

Tidal level (rather than fluvial flooding) was found to be the most important driver, in both present-day and future climate change scenarios for both estuary systems (Dyfi and Humber); hence, estuarine systems are sensitive to sea-level rise, as tides modulate about this mean level for the outer estuary (due to greater flood extent), whilst the inner estuary appears less vulnerable to increased surge height (Figs. 9, 10 and 13). Further, SLR scenarios resulted with flooding in areas of socio-economic importance located in the outer estuary (urban and industry regions) and a higher risk to the Hull defence barrier.

The Dyfi estuary is a shorter estuary with a quickly responding fluvial system, and flooding was found to be least sensitive to changes in surges than SLR or fluvial changes. However, flooding in the Dyfi was sensitive to surge type (short- or long-duration, D13 and D14, respectively), meaning the total volume of water during a surge event is important (Fig. 12): as found by Quinn et al. (2014). The height of the peak surge at high tide in relation to tidal range affects its ability to travel upstream in the Dyfi estuary due to the constriction of the Dovey Junction bridge at the top of the estuary (Fig. 12). This means that, although maximum water depths are still increased in the lower fluvial region, flooding is not as extensive as it would be if the constriction was not there. In comparison to SLR of the same height, the same behaviour of maximum water depths occurred, where a surge resulted in higher in-estuary maximum water depths (Figs. 10 and 13), but much less overbank flooding and therefore a much-reduced spatial impact compared to SLR. For the climate change scenarios, SLR is the most important driver in the Dyfi (D10). Due to the higher surrounding topography and smaller area, the upper estuary is strongly impacted by SLR, more so than in the Humber.

Future work could investigate the applicability of our findings to a much wider range of estuary shapes and types. For example, the volume of the fluvial flood extreme within the risk window (tide above mean-sea-level), normalised by the available volume of the estuary before flooding (defined from the surge duration and tide conditions above mean sealevel—and thus could include sea-level rise scenarios), may be one metric to standardise the compound estuary flood hazard. Short estuaries with quickly responding fluvial systems (e.g. steep mountain topography) may have the highest risk associated within the inner estuary which are sensitive to both timing and magnitude of fluvial input, whilst larger estuaries with slower responding catchments appear to have the highest risk associated with the tide-surge component: 
however, many more systems ought to be tested to prove such a theory.

\section{Conclusion}

Uncertainty in projected future changes to extreme fluvial floods and sea-levels has led to concern of a future increase to compound flood hazards in estuaries. Two contrasting UK estuaries were found to be sensitive to variability in the co-occurrence of fluvial, tidal and storm surge extremes. Therefore, future estuary flood risk can increase even if flood hazard sources and drivers do not (i.e. future changes to joint probability of extremes may be as important as changes to return periods of extremes). For the present-day worst case: the upper estuary of a quick response system (Dyfi) was most impacted by a fluvial flood extreme, with timing of the fluvial extreme to storm-tide extreme having the great impact to inundation throughout the estuary. In the slower response system (Humber), sensitivity to timing was much lower (as the fluvial extreme persisted for more than one high tide) and hence sensitive to the magnitude of fluvial extreme only; with an increase in inundation vulnerability in the inner estuary but a decrease of water-levels in the outer estuary-most likely because of the lower dynamic head (as the fluvial input decreased water-level difference of estuary and the ocean) and estuary geometry (Spurn Point) constricting the flow of the storm-tide hazard driver into the estuary.

In both systems, potential climate change driven future flood risk scenarios showed the outer estuary to be the most vulnerable as the increase in fluvial magnitude moves the zone of elevated water-levels downstream-further to the outer estuary-and the storm-tide hazard drivers increase the outer estuary vulnerability. Therefore, sub-daily scale probabilistic analysis of compound hazard drivers appears important for small quickly responding estuarine systems, whilst daily-scale probabilistic analysis appears appropriate for larger-scale and slower responding estuaries. Our results indicate the vulnerability of compound hazard events increases under our future climate change scenarios, and continual investment in flood defences is likely to be required to mitigate the increasing flood risk for estuaries.

Acknowledgements We would like to thank Dr Gemma Coxon for providing high-resolution processed fluvial gauge data, and Dr Chris Skinner for providing advisement and data for the Humber estuary. This research contains Natural Resources Wales information (C) Natural Resources Wales and Database Rights. All rights reserved. The data used in this study is available, on request, from the Environment Agency and the Association of British Ports and was provided to this study on a non-commercial license. The CAESAR-Lisflood model can be downloaded from www.coulthard.org.uk.

Funding This work was funded by the NERC CHEST (NE/R009007/1) and the NERC SEARCH (NE/V004239/1) grants, and Matt Lewis also wishes to acknowledge funding from the EPSRC METRIC grant (EP/ R034664/1). The work described in this publication was supported by the European Community's Horizon 2020 Programme through the grant to the budget of the Integrated Infrastructure Initiative HYDRALAB +, contract no. 654110 .

Open Access This article is licensed under a Creative Commons Attribution 4.0 International License, which permits use, sharing, adaptation, distribution and reproduction in any medium or format, as long as you give appropriate credit to the original author(s) and the source, provide a link to the Creative Commons licence, and indicate if changes were made. The images or other third party material in this article are included in the article's Creative Commons licence, unless indicated otherwise in a credit line to the material. If material is not included in the article's Creative Commons licence and your intended use is not permitted by statutory regulation or exceeds the permitted use, you will need to obtain permission directly from the copyright holder. To view a copy of this licence, visit http://creativecommons.org/licenses/by/4.0/.

\section{References}

Bates, P.D., M.S. Horritt, and T.J. Fewtrell. 2010. A simple inertial formulation of the shallow water equations for efficient twodimensional flood inundation modelling. Journal of Hydrology 387: 33-45. https://doi.org/10.1016/j.jhydrol.2010.03.027.

Bates, P.D., R.J. Dawson, J.W. Hall, M.S. Horritt, R.J. Nicholls, J. Wicks, and M.A. Ali Mohamed Hassan. 2005. Simplified twodimensional numerical modelling of coastal flooding and example applications. Coastal Engineering 52: 793-810. https://doi.org/10. 1016/j.coastaleng.2005.06.001.

Bevacqua, E., D. Maraun, M.I. Vousdoukas, E. Voukouvalas, M. Vrac, L. Mentaschi, and M. Widmann. 2019. Higher probability of compound flooding from precipitation and storm surge in Europe under anthropogenic climate change. Science Advances 5: 1-8. https://doi.org/10.1126/sciadv.aaw5531.

Beven, K.J., and M.J. Kirkby. 1979. A physically based, variable contributing area model of basin hydrology. Hydrological Sciences Bulletin 24: 43-69. https://doi.org/10.1080/02626667909491834.

Brown, J.M., and A.G. Davies. 2010. Flood/ebb tidal asymmetry in a shallow sandy estuary and the impact on net sand transport. Geomorphology 114: 431-439. https://doi.org/10.1016/j.geomorph. 2009.08.006.

Coulthard, T.J., J.C. Neal, P.D. Bates, J. Ramirez, G.A.M. de Almeida, and G.R. Hancock. 2013. Integrating the LISFLOOD-FP 2D hydrodynamic model with the CAESAR model: Implications for modelling landscape evolution. Earth Surface Processes and Landforms 38: 1897-1906. https://doi.org/10.1002/esp.3478.

Dausse, A., A. Garbutt, L. Norman, S. Papadimitriou, L.M. Jones, P.E. Robins, and D.N. Thomas. 2012. Biogeochemical functioning of grazed estuarine tidal marshes along a salinity gradient. Estuarine, Coastal and Shelf Science 100: 83-92. https://doi.org/10.1016/j. ecss.2011.12.037

Debernard, J.B., and L.P. Røed. 2008. Future wind, wave and storm surge climate in the Northern Seas: A revisit. Tellus, Series A: Dynamic Meteorology and Oceanography 60A: 427-438. https:// doi.org/10.1111/j.1600-0870.2008.00312.x.

Ehret, U., et al. 2014. Advancing catchment hydrology to deal with predictions under change. Hydrology and Earth System Sciences 18: 649-671. https://doi.org/10.5194/hess-18-649-2014.

Haigh, I.D., O. Ozsoy, R.J. Nicholls, J.M. Brown, B. Gouldby, T. Wahl, K. Horsburgh, and M.P. Wadey. 2016. Spatial and temporal analysis of extreme sea level and storm surge events around 
the coastline of the UK. Scientific Data 1-14. https://doi.org/10. 1038/sdata.2016.107.

Hannaford, J. 2015. Climate-driven changes in UK river flows: A review of the evidence. Progress in Physical Geography 39: 29-48. https://doi.org/10.1177/0309133314536755.

Hendry, A., I.D. Haigh, R.J. Nicholls, H. Winter, R. Neal, T. Wahl, A. Joly-Lauge, and S.E. Darby. 2019. Assessing the characteristics and drivers of compound flooding events around the UK coast. Hydrology and Earth System Sciences 23. https://doi.org/10.5194/ hess-23-3117-2019.

Hoegh-Guldberg, O., D. Jacob, M. Taylor, M. Bindi, S. Brown, I. Camilloni, A. Diedhiou, R. Djalante, K.L. Ebi, F. Engelbrecht, J. Guiot, Y. Hijioka, S. Mehrotra, A. Payne, S.I. Seneviratne, A. Thomas, R. Warren, and G. Zhou. 2018. Impacts of $1.5^{\circ} \mathrm{C}$ Global Warming on Natural and Human Systems. In Global Warming of $1.5{ }^{\circ} \mathrm{C}$. An IPCC Special Report on the impacts of global warming of $1.5^{\circ} \mathrm{C}$ above pre-industrial levels and related global greenhouse gas emission pathways, in the context of strengthening the global response to the threat of climate change, [MassonDelmotte, V., P. Zhai, H.-O. Pörtner, D. Roberts, J. Skea, P.R. Shukla, A. Pirani, W. Moufouma-Okia, C. Péan, R. Pidcock, S. Connors, J.B.R. Matthews, Y. Chen, X. Zhou, M.I. Gomis, E. Lonnoy, T. Maycock, M. Tignor and TW (ed). In Press.

Kappes, M.S., M. Keiler, K. von Elverfeldt, and T. Glade. 2012. Challenges of analyzing multi-hazard risk: A review. Natural Hazards 64: 1925-1958. https://doi.org/10.1007/s11069-012-0294-2.

King, D.A. 2004. Climate change science: Adapt, mitigate, or ignore? Science 303: 176-177.

Klerk, W.J., H.C. Winsemius, W.J. Van Verseveld, A.M.R. Bakker, and F.L.M. Diermanse. 2015. The co-incidence of storm surges and extreme discharges within the Rhine-Meuse Delta. Environmental Research Letters 10. https://doi.org/10.1088/1748-9326/ 10/3/035005.

Kumbier, K., R.C. Carvalho, A.T. Vafeidis, and C.D. Woodroffe. 2018. Investigating compound flooding in an estuary using hydrodynamic modelling: A case study from the Shoalhaven River, Australia. Natural Hazards and Earth System Sciences 18: 463-477. https://doi.org/10.5194/nhess-18-463-2018.

Law, M., P. Wass, and D. Grimshaw. 1997. The hydrology of the Humber catchment. Science of the Total Environment 194-195: 119-128. https://doi.org/10.1016/S0048-9697(96)05357-0.

Lewis, M., K. Horsburgh, P. Bates, and R. Smith. 2011. Quantifying the Uncertainty in Future Coastal Flood Risk Estimates for the U.K. Journal of Coastal Research 276: 870-881. https://doi.org/ 10.2112/jcoastres-d-10-00147.1.

Lewis, M., P. Bates, K. Horsburgh, J. Neal, and G. Schumann. 2013. A storm surge inundation model of the northern Bay of Bengal using publicly available data. Quarterly Journal of the Royal Meteorological Society 139: 358-369. https://doi.org/10.1002/qj.2040.

Lewis, M.J., T. Palmer, R. Hashemi, P. Robins, A. Saulter, S. Neill, J. Brown, and H. Lewis. 2019. Wave-tide interaction modulates nearshore wave height. Ocean Dynamics 69: 367-384. https://doi. org/10.1007/s10236-018-01245-z.

Lowe, J.A., et al. 2019. UKCP18 Science Overview Report [online] Available from: https://www.metoffice.gov.uk/pub/data/weather/ uk/ukcp18/science-reports/UKCP18-Overview-report.pdf.

Lowe, J.A., J.M. Gregory, and R.A. Flather. 2001. Changes in the occurrence of storm surges around the United Kingdom under a future climate scenario using a dynamic storm surge model driven by Hadley Centre climate models. Climate Dynamics 18: 179-188. https://doi.org/10.1007/s003820100163.

Lyddon, C., J.M. Brown, N. Leonardi, and A.J. Plater. 2018. Flood hazard assessment for a hyper-tidal estuary as a function of tidesurge-morphology interaction. Estuaries and Coasts 41: 15651586. https://doi.org/10.1007/s12237-018-0384-9.
Mansur, A.V., E.S. Brondízio, S. Roy, S. Hetrick, N.D. Vogt, and A. Newton. 2016. An assessment of urban vulnerability in the Amazon Delta and Estuary: A multi-criterion index of flood exposure, socio-economic conditions and infrastructure. Sustainability Science 11: 625-643. https://doi.org/10.1007/s11625-016-0355-7.

Maskell, J., K. Horsburgh, M. Lewis, and P. Bates. 2014. Investigating river-surge interaction in idealised estuaries. Journal of Coastal Research 30: 248-259. https://doi.org/10.2112/jcoastresd-12-00221.1.

Met Office. 2019. https://www.metoffice.gov.uk/binaries/content/assets/ metofficegovuk/pdf/weather/learn-about/uk-pastevents/summa ries/uk_monthly_climate_summary_summer_2019.pdf

Milly, P.C.D., J. Betancourt, M. Falkenmark, R.M. Hirsch, Z.W. Kundzewicz, D.P. Lettenmaier, and R.J. Stouffer. 2008. Climate change: Stationarity is dead: Whither water management? Science 319: 573-574. https:// doi.org/10.1126/science.1151915.

Monbaliu, J., et al. 2014. Risk assessment of estuaries under climate change: Lessons from Western Europe. Coastal Engineering 87: 32-49. https://doi.org/10.1016/j.coastaleng.2014.01.001.

Muis, S., M. Verlaan, H.C. Winsemius, J.C.J.H. Aerts, and P.J. Ward. 2016. A global reanalysis of storm surges and extreme sea levels. Nature Communications 7. https://doi.org/10.1038/ ncomms 11969.

Neal, J., G. Schumann, T. Fewtrell, M. Budimir, P. Bates, and D. Mason. 2011. Evaluating a new LISFLOOD-FP formulation with data from the summer 2007 floods in Tewkesbury, UK. Journal of Flood Risk Management 4: 88-95. https://doi.org/10.1111/j. 1753-318X.2011.01093.x.

Nicholls, R.J., and A. Cazenave. 2010. Sea-level rise and its impact on coastal zones. Science 328: 1517-1520. https://doi.org/10.1126/ science. 1185782 .

Nicholls, R.J., N. Marinova, J.A. Lowe, S. Brown, P. Vellinga, D. De Gusmão, J. Hinkel, and R.S.J. Tol. 2011. Sea-level rise and its possible impacts given a "beyond $4^{\circ} \mathrm{C}$ world" in the twentyfirst century. Philosophical Transactions of the Royal Society A: Mathematical, Physical and Engineering Sciences 369: 161-181. https://doi.org/10.1098/rsta.2010.0291.

Orton, P.M., F.R. Conticello, F. Cioffi, T.M. Hall, N. Georgas, U. Lall, A.F. Blumberg, and K. MacManus. 2018. Flood hazard assessment from storm tides, rain and sea level rise for a tidal river estuary. Natural Hazards 1-29. https://doi.org/10.1007/ s11069-018-3251-x.

Petroliagkis, T.I., E. Voukouvalas, J. Disperati, and J. Bidlot. 2016. Joint probabilities of storm surge, significant wave height and river discharge components of coastal flooding events [online] Available from: https://core.ac.uk/download/pdf/38632343.pdf.

Pugh, D., and P. Woodworth. 2014. Sea-Level Science

Pye, K., and S.J. Blott. 2014. The geomorphology of UK estuaries: The role of geological controls, antecedent conditions and human activities. Estuarine, Coastal and Shelf Science 150: 196-214. https://doi.org/10.1016/j.ecss.2014.05.014[online]Availablefrom: doi:10.1016/j.ecss.2014.05.014.

Quinn, N., M. Lewis, M.P. Wadey, and I.D. Haigh. 2014. Assessing the temporal variability in extreme storm-tide time series for coastal flood risk assessment. Journal of Geophysical Research: Oceans 119: 4983-4998. https://doi.org/10.1002/2014JC010197.

Ramirez, J.A., M. Lichter, T.J. Coulthard, and C. Skinner. 2016. Hyperresolution mapping of regional storm surge and tide flooding: Comparison of static and dynamic models. Natural Hazards 82: 571-590. https://doi.org/10.1007/s11069-016-2198-z.

RMS. 2007. 1947 U.K. river floods: 60-year retrospective [online] Available from: https://support.rms.com/publications/1947 UKRiverFloods.pdf.

Robins, P.E., et al. 2016. Impact of climate change on UK estuaries: A review of past trends and potential projections. Estuarine, Coastal 
and Shelf Science 169: 119-135. https://doi.org/10.1016/j.ecss. 2015.12.016.

Robins, P.E., and A.G. Davies. 2010. Morphological controls in sandy estuaries: the influence of tidal flats and bathymetry on sediment transport. Ocean Dynamics 60 (3): 503-517. https://doi.org/10. 1007/s10236-010-0268-4.

Robins, P.E., A.G. Davies, and R. Jones. 2011. Application of a coastal model to simulate present and future inundation and aid coastal management. Journal of Coastal Conservation 15: 1-14. https:// doi.org/10.1007/s11852-010-0113-4.

Robins, P.E., M.J. Lewis, J. Freer, D.M. Cooper, C.J. Skinner, and T.J. Coulthard. 2018. Improving estuary models by reducing uncertainties associated with river flows. Estuarine, Coastal and Shelf Science 207: 63-73. https://doi.org/10.1016/j.ecss.2018.02.015.

Santos, V.M., I.D. Haigh, and T. Wahl. 2017. Spatial and Temporal Clustering Analysis of Extreme Wave Events Around the Uk Coastline. Journal of Marine Science and Engineering 5: 19. https://doi.org/10.3390/jmse5030028.

Shi, Z. 1993. Recent saltmarsh accretion and sea level fluctuations in the Dyfi Estuary central Cardigan Bay Wales UK. Geo-Marine Letters 13 (3): 182-188. https://doi.org/10.1007/BF01593192.

Skinner, C.J., T.J. Coulthard, D.R. Parsons, J.A. Ramirez, L. Mullen, and S. Manson. 2015. Simulating tidal and storm surge hydraulics with a simple 2D inertia based model, in the Humber Estuary, U.K. Estuarine, Coastal and Shelf Science 155: 126-136. https:// doi.org/10.1016/j.ecss.2015.01.019.

Slingo, J., S. Belcher, A. Scaife, M. McCarthy, A. Saulter, K. McBeath, A. Jenkins, C. Huntingford, T. Marsh, and J. Hannaford. 2014. The recent storms and floods in the UK [online] Available from: http://www.metoffice.gov.uk/media/pdf/n/i/Recent_Storms_Brief ing_Final_07023.pdf.

Svensson, C., and D.A. Jones. 2002. Dependence between extreme sea surge, river flow and precipitation in eastern Britain. International Journal of Climatology 22: 1149-1168. https://doi.org/10.1002/ joc.794.

Svensson, C., and D.A. Jones. 2004. Dependence between sea surge, river flow and precipitation in south and west Britain. Hydrology and Earth System Sciences 8: 973-992. https://doi.org/10.5194/hess-8-973-2004.

Teng, J., A.J. Jakeman, J. Vaze, B.F.W. Croke, D. Dutta, and S. Kim. 2017. Flood inundation modelling: A review of methods, recent advances and uncertainty analysis. Environmental Modelling and Software 90: 201-216. https://doi.org/10.1016/j.envsoft.2017.01. 006.

Townend, I., and P. Whitehead. 2003. A preliminary net sediment budget for the Humber Estuary. The Science of The Total Environment 314316755-767 https://doi.org/10.1016/S0048-9697(03)00082-2

Van Den Hurk, B., E. Van Meijgaard, P. De Valk, K.J. Van Heeringen, and J. Gooijer. 2015. Analysis of a compounding surge and precipitation event in the Netherlands. Environmental Research Letters 10. https://doi.org/10.1088/1748-9326/10/3/035001.
Vousdoukas, M.I., E. Voukouvalas, L. Mentaschi, F. Dottori, A. Giardino, D. Bouziotas, A. Bianchi, P. Salamon, and L. Feyen. 2016. Developments in large-scale coastal flood hazard mapping. Natural Hazards and Earth System Sciences 16: 1841-1853. https://doi.org/10.5194/nhess-16-1841-2016.

Wade, A.J., C. Neal, P.G. Whitehead, and N.J. Flynn. 2005. Modelling nitrogen fluxes from the land to the coastal zone in European systems: A perspective from the INCA project. Journal of Hydrology 304: 413-429. https://doi.org/10.1016/j.jhydrol.2004.07.041.

Wahl, T., S. Jain, J. Bender, S.D. Meyers, and M.E. Luther. 2015. Increasing risk of compound flooding from storm surge and rainfall for major US cities. Nature Climate Change 5: 1093-1097. https://doi.org/10.1038/nclimate2736.

Ward, P.J., A. Couasnon, D. Eilander, I.D. Haigh, A. Hendry, S. Muis, T.I.E. Veldkamp, H.C. Winsemius, T. Wahl. 2018. Dependence between high sea-level and high river discharge increases flood hazard in global deltas and estuaries. Environmental Research Letters 13. https://doi.org/10.1088/1748-9326/aad400.

Williams, J., K.J. Horsburgh, J.A. Williams, and R.N.F. Proctor. 2016. Tide and skew surge independence: New insights for flood risk. Geophysical Research Letters 43: 6410-6417. https://doi.org/10. 1002/2016GL069522.

Winter, B., K. Schneeberger, M. Huttenlau, and J. Stötter. 2018. Sources of uncertainty in a probabilistic flood risk model. Natural Hazards 91 (2): 431-446. https://doi.org/10.1007/s11069-017-3135-5.

Wolf, J. 2009. Coastal flooding: Impacts of coupled wave-surge-tide models. Natural Hazards 49: 241-260. https://doi.org/10.1007/ s11069-008-9316-5.

Woth, K., R. Weisse, and H. Von Storch. 2006. Climate change and North Sea storm surge extremes: An ensemble study of storm surge extremes expected in a changed climate projected by four different regional climate models. Ocean Dynamics 56: 3-15. https://doi.org/10.1007/s10236-005-0024-3.

Yin, J., N. Lin, and D. Yu. 2016. Coupled modeling of storm surge and coastal inundation: A case study in New York City during Hurricane Sandy. Water Resources Research 52: 8685-8699. https:// doi.org/10.1002/2016WR019102.

Zellou, B., and H. Rahali. 2019. Assessment of the joint impact of extreme rainfall and storm surge on the risk of flooding in a coastal area. Journal of Hydrology 569: 647-665. https://doi.org/ 10.1016/j.jhydrol.2018.12.028.

Zheng, F., S. Westra, and S.A. Sisson. 2013. Quantifying the dependence between extreme rainfall and storm surge in the coastal zone. Journal of Hydrology 505: 172-187. https://doi.org/10.1016/j. jhydrol.2013.09.054.

Zhong, H., P.-J. van Overloop, and P.H.A.J.M. van Gelder. 2013. A joint probability approach using a 1-D hydrodynamic model for estimating high water level frequencies in the Lower Rhine Delta. Natural Hazards and Earth System Sciences 13: 1841-1852. https://doi.org/10.5194/nhess-13-1841-2013. 